\title{
Aid and Growth Evidence from Firm-level Data
}

\author{
Lisa Chauvet* \\ Hélène Ehrhart ${ }^{\dagger}$
}

October 14,2014

\section{Abstract}

This paper explores the impact of foreign aid on firms growth for a panel of 5,640 firms in 29 developing countries, 11 of which in Africa. Using the World Bank Enterprise Surveys data and controlling for firms fixed effects, we find a positive impact of foreign aid on sales growth. This result is robust to various checks, notably to the instrumentation of aid. We then identify the main infrastructure obstacles to firms growth and examine whether foreign aid contributes to relaxing those constraints. We find that electricity and transport are perceived as important constraints which tend to decrease the growth rate of firms, as well as the utilization of their productive capacity. Evidence on the impact of aid on infrastructure obstacles suggests that total aid and aid to the energy sector tend to decrease electricity obstacles. We also show that transport aid projects, geo-localized at the region level, tend to decrease the transport obstacles.

Keywords: Foreign aid. Firms growth. Infrastructures constraints.

JEL codes: F35, O16, O50

*(1) IRD, LEDa, DIAL UMR 225, Banque de France, PSL, Université Paris-Dauphine, FERDI.

${ }^{\dagger}$ Banque de France.

We wish to thank Agnès Dufour for amazing research assistance. We also wish to thank Sanvi Avouyi-Dovi, Antoine Berthou, Bruno Cabrillac, Christian Durand, Patrick Guillaumont, Sylviane Guillaumont Jeanneney, Jérôme Héricourt, Luc Jacolin, Katja Michaelowa, Henri Pagès, Sandra Poncet and Emmanuel Rocher for useful discussions. We also thank the participants of the ABCA and AEL conferences for useful comments. This paper is a product of the Franc Zone and Development Financing Studies Division (COMOZOF) of the Banque de France. It reflects the opinions of the authors and do not necessarily express the views of the Banque de France. The usual disclaimers apply. 


\section{Introduction}

The impact of aid on growth has been highly debated over the last decade, without any consensus emerging. Some authors have argued that aid is effective in spurring economic growth depending on specific characteristics of the developing countries such as the quality of their macroeconomic policy (Burnside and Dollar, 2000), their exposure to external shocks (Guillaumont and Chauvet, 2001; Collier and Dehn, 2001), their structural handicaps (Dalgaard et al., 2004). Those studies adopt a cross-country approach and all suffer from similar methodological weaknesses, the endogeneity of aid being poorly addressed. Using a better identification strategy based on a gravity model for bilateral aid flows, Rajan and Subramanian (2008) find hardly no effect of aid on aggregate growth.

In this article, we build on the existing literature on aid effectiveness but rely on more disaggregated data to assess its impact on growth. We examine how aid affects firms growth in a panel of 29 developing countries, using the World Bank Enterprise Surveys (WBES) panel datasets.

Aid may affect firms growth by relieving different constraints faced by firms. Aid to infrastructure and aid for trade may contribute to firms getting a better access to markets. Aid to electrical infrastructure may relax the electricity shortages weighting on their production. Inversely, aid may also induce a loss of competitiveness through a Dutch disease effect, as underlined by Rajan and Subramanian (2011).

To explore the impact of aid on firms growth, we compiled a panel dataset stacking firm-level data from the WBES. It is composed of more than 5,000 firms in 29 countries, for which we have two points in time depending on the years the surveys were conducted. Those firms surveys provide information on the growth rate of sales, but also on various other characteristics of the firms - its ownership, its size, its sector of activity. Among those characteristics, the WBES also provide information on the various obstacles to their activity (infrastructure constraints, financing constraints, legal and institutional constraints). In order to assess the impact of aid on firms growth, we combine this panel of firm-level data with macroeconomic variables such as foreign aid, income per capita, the quality of institutions.

There are various sources of endogeneity in the relationship we intend to estimate. Aid is endogeneous to economic performance since donors allocate aid purposively and are likely to react to countries growth performance. One major advantage of examining the impact of aid on a disaggregated outcome such as firms growth is that it considerably attenuates this source of endogeneity concern. Reverse causality (from firms growth to aid allocation) is much less likely than when looking at aggregate growth. Moreover, stacking panel data for firms has rarely been done for developing economies and also presents important advantages when dealing with the endogeneity of aid. Indeed, firms fixed-effects allow to control for time-invariant 
heterogeneity, which may otherwise induce an endogeneity bias. The main source of endogeneity which remains is time-varying unobservable heterogeneity. To fully address the issue of aid endogeneity, we thus instrument aid. Following Rajan and Subramanian (2008) and Tavares (2003), we find an exogenous source of variation of aid in the change of total fiscal revenue of donor countries, weighted by the cultural distance between pairs of donor-receiving countries.

The article is structured as follows. After having presented the relevant literature (Section 2), we describe the model and data (Section 3). The benchmark results and various robustness checks are detailed in Section 4. Section 5 presents indirect evidence for the absence of Dutch disease. In Section 6 we examine the impact of aid on the infrastructure obstacles to firms growth. Finally, Section 7 concludes.

\section{Aid effectiveness and the constraints on growth: a review of the debates}

\subsection{The impact of aid on growth}

A large body of the literature on aid effectiveness has explored the impact of aid on aggregate growth rates at the country-level. Since the work of Burnside and Dollar (2000), a flourishing literature has emerged, examining which recipients' characteristics may make aid more or less effective in terms of growth. A large array of conditions have been found to influence aid effectiveness: the quality of policy choices (Burnside and Dollar (2000)), geography (Dalgaard et al., 2004), exposure to external shocks (Guillaumont and Chauvet, 2001; Collier and Dehn, 2001), post-conflict situations (Collier and Hoeffler, 2004), characteristics of the elite (Angeles and Neanidis, 2009), and the list is not exhaustive. The exponential number of findings on the conditions that affect the aid-growth relationship are difficult to reconcile one with the others and make it difficult to conclude about what really matters for aid effectiveness. Two contributions are particularly helpful to draw some conclusions from this literature. First, Roodman (2007) provides insightful robustness checks of the most cited studies on the conditions for aid effectiveness. He finds that post-conflict situations and geography seem to be more robust to changes in specification, changes in aid definition, extension of the sample and exclusion of outliers. Second, Hansen and Tarp (2000) and Hansen and Tarp (2001) show that the non-linearity in the aid-growth relationship is best captured by marginal decreasing returns of aid, than

with any other interaction term. Thus if anything was to be concluded from this literature, it may well be that the absorptive capacity of aid is limited and that aid has marginal diminishing returns, which are better 
captured by an aid squared term, but which may as well be proxied by the quality of policy, vulnerability of external shocks, geography etc.

This literature on the aggregate effect of aid on growth has been largely criticized for the lack of robustness of the results, on two grounds: (1) the weak treatment of the endogeneity of aid ; (2) the aggregation of aid and of the outcomes on which aid effectiveness is assessed. Both relate to the contribution of this article to the literature and are presented in what follows.

One major criticism was formulated by Rajan and Subramanian and refers to the weak treatment of endogeneity in the articles examining the aid-growth relationship. The endogeneity of aid is fully recognized: donors provide aid purposively and their aid allocation reflects their own objectives as well as the economic challenges of the receiving countries. Before the contributions of Tavares $(2003)^{1}$ and Rajan and Subramanian (2008) the treatment of aid endogeneity was relying on instrumental variables procedures using specific characteristics of the receiving countries as instruments: dummies for colonial past, dummies for strategic interest (like 'Zone Franc', Latin America, Egypt, Israel), arms imports, child mortality, lagged income, population. But of course this set of instruments does not meet the required conditions to be considered as valuable instruments, notably the excludability condition. One solution to this problem consists in instrumenting aid using the so-called 'supply-side' instruments. Those instruments exploit the exogenous variation in aid allocation which stems from the economic or political situation in the donor countries. Tavares (2003) uses the weighted average of total aid budget of the 22 DAC donors, where the weights capture the bilateral (geographic and cultural) distance between each pair of donor-recipient. In the same vein, Rajan and Subramanian (2008) use a gravity model to estimate bilateral aid flows using structural determinants (colonial past, relative size of the recipient) and use the sum of those estimated flows as an instrument for aid received by each developing country. And the conclusion of Rajan and Subramanian's work sharply differs from what was previously found: once properly instrumented, aid has no impact on growth - or when it has, it is negative. ${ }^{2}$ Their explanation for this negative impact is provided in a companion article - Rajan and Subramanian (2011) - in which they evidence the Dutch disease effect of aid using industry-level data.

The second set of criticisms that was addressed to the literature on the aggregate impact of aid on growth is that aid is composed of various heterogeneous flows which objectives are not necessarily short-term economic growth. The solutions provided so-far to tackle this issue have been three-fold: either disaggregate aid into its various components ; or disaggregate the outcome on which aid effectiveness is assessed ; or

\footnotetext{
${ }^{1}$ In this article, Tavares (2003) is not looking at the impact of aid on growth but he rather examines the impact of aid on corruption.

${ }^{2}$ For a criticism of Rajan and Subramanian (2008), see Arndt et al. (2010).
} 
both. The first attempt to disaggregate aid was provided by Clemens et al. (2011). In their article, the authors distinguish early-aid from the rest of it and find that early-aid, which is meant to improve economic growth has indeed the expected effect. ${ }^{3}$ Some other authors have looked at the impact of aggregate aid on economic outcomes disaggregated at the country-level. This is for example the case of Chauvet and Mesplé-Somps (2007) and Bjørnskov (2010) who both look at the impact of aid on intra-country inequality using a panel data-set of income disaggregated by decile or quintile in more than 80 developing countries. Both articles conclude that the impact of aid on inequality depends on the characteristics of the political institutions, and whether the country is democratic or not. Finally, some authors have disaggregated aid and the outcome on which its effectiveness is assessed. Using intra-country data on health outcomes for a panel of developing countries (stacking the Demographic and Health surveys), Chauvet et al. (2013) and Ebeke and Drabo (2011) find that aid to the health sector actually improves health outcomes in receiving countries. ${ }^{4}$ One shortcoming of looking at the impact of sector aid on intra-country outcomes is that aid has never so far been geo-localized on receiving countries' territory, hence attenuating the advantage of looking at intra-country variations in the outcome.

In this article, we assess aid effectiveness using firms' growth outcomes, instead of aggregated growth. Our approach is therefore close to that of Rajan and Subramanian (2011) who explore the impact of aid on the growth of value added measured at the industry-level. Because firms are geo-localized at the region-level in our dataset, we have also geo-localized part of aid projects to the infrastructure sector in order to better assess its impact on firms growth.

\subsection{What are the impediments to firms' growth in developing countries?}

The literature emphasizes three main kinds of constraints to firms' growth in developing countries: (1) financial constraints, (2) the global macroeconomic and institutional environment and business climate, and (3) infrastructure.

Using firm-level data, financial factors have been found to be a large constraint to the performance of firms in developing countries. Beck et al. (2005) show that individual financing obstacles such as credit access, collateral requirements or bank bureaucracies do constrain firms' growth. Moreover, weak access to finance reduces firms' probability to enter into the export market (Berman and Héricourt, 2010) and prevent

\footnotetext{
${ }^{3}$ Early-aid includes "budget support or 'program' aid given for any purpose and project aid given for real sector investments for infrastructure or to directly support production in transportation (including roads), communications, energy, banking, agriculture and industry." (Clemens et al. (2011) page 598).

${ }^{4}$ Results on the education sector go in the same direction, even though the data used to measure the education outcome do not display any intra-country variation. Michaelowa and Weber (2006) and Dreher et al. (2008) show that aid to the education sector has a positive impact on education outcomes, notably in countries where governance is of high quality.
} 
them from importing needed capital goods (Bas and Berthou, 2012).

The global macroeconomic and institutional environment of a country also affects significantly the way firms can profitably develop their activities. In particular, Fisman and Svensson (2007) and Chong and Gradstein (2009) respectively show that corruption and the volatility of economic policies tend to reduce firms' growth.

A large body of the literature underlines the critical role of the provision of infrastructure, through its various dimensions of transport, energy, telecommunications and water, for economic development (see among others Calderon and Serven (2008), Rud (2012), Straub (2008)). Infrastructure have been shown to be quantitatively important in determining transport costs (Limao and Venables, 2001), and in ensuring access to the inputs and to the markets. At a more disaggregated level, several studies also found that a lack of infrastructure significantly undermines the growth of firms. Using firm-level data on Bangladesh, China, India, and Pakistan, Dollar et al. (2005) find that factor returns, growth and accumulation of firms are higher the lower the bottlenecks such as the number of days to clear goods through customs, days to get a telephone line or sales lost to power outages. Harrison et al. (2013) underline that the lack of good infrastructure, proxied by telecommunication infrastructure, is one of the key explanation of Africa's disadvantage in firms performance, compared to other regions. In these countries, indirect costs, related to infrastructure and services, represent a large burden on the competitiveness of the firms (Eifert et al., 2008). In India, Mitra et al. (2002) and Datta (2012) also evidenced that infrastructure endowment substantially fosters the performance of the industrial sector.

Given that the lack of adequate infrastructure can be such an obstacle to firms growth, and since large amounts of aid are devoted to building infrastructure, we will investigate whether aid helps foster the growth of firms through its provision of basic infrastructure.

\section{$3 \quad$ Model and data}

We investigate the impact of foreign aid on firms growth using the general following specification:

$$
\text { Firmsgrowth }_{i, k, j, t}=\alpha+\beta X_{i, k, j, t}+\gamma Y_{j, t}+\mu_{i}+\tau_{k, t}+\varepsilon_{i, k, j, t}
$$

where Firmsgrowt $h_{i, k, j, t}$ is the average annual growth rate of the sales of firm $i$ in industry $k$, country $j$ and time $t$. The growth rate is computed over three years. $\mathrm{X}_{i, k, j, t}$ is a set of time-varying firm-level characteristics, while $\mathrm{Y}_{j, t}$ is a set of country-level variables including foreign aid. We include firms fixed 
effects, $\mu_{i}$, as well as industry x year dummies, $\tau_{k, t}$.

\subsection{Firm-level panel data}

We constructed a large dataset at the firm-level combining all the World Bank Enterprise Surveys (WBES) available in panel in September 2013. ${ }^{5}$ These surveys cover a representative sample of an economy's manufacturing and services sectors. In each country, data were gathered through an extensive questionnaire answered during a face-to-face interview by business owners and top managers. They represent a comprehensive and comparable source of firm-level data since the survey questions are the same across all countries and years. The sample of countries and years is presented in Appendix 1.

Data in local currencies have been converted into US dollars and deflated using the same base year (100 $=2005)$. GDP deflators and exchange rates are obtained from the IMF's International Financial Statistics (IFS). After harmonization across countries, the panel dataset comprises more than 5,000 firms from 29 developing countries observed twice in time (details in Appendix 1). We did not consider surveys from Angola (2006, 2010), the Democratic Republic of Congo (2006, 2010) and Afghanistan (2005, 2009) since those three countries experienced violent events and benefited from higher than normal growth rates and/or aid amounts, driving artificially upwards our results on the effect of aid on growth. ${ }^{6}$

WBES include information on the sales in the year preceding the survey, as well as three years before. This allows us to compute the growth rate of sales over three years for each survey available. For some countries the time span is slightly different, depending on the years for which the questions have been asked. ${ }^{7}$ We rely on the existing literature (see notably Beck et al. (2005)) and account for the following firms characteristics:

- $\mathrm{GROWTH}_{i, k, j, t}$ : Growth rate of the sales of the firm computed between $t$ and $t$-3. Sales are converted into US dollars and deflated.

- SALES $\mathrm{S}_{i, k, j, t-3}$ : Logarithm of the lagged sales. It is most of the time measured in $t$-3, with some exceptions. Sales are converted into US dollars and deflated.

- $\operatorname{EXPORTS}_{i, k, j, t}$ : Dummy variable which is equal to one when the firm is exporting part or all its sales, either directly or indirectly.

\footnotetext{
${ }^{5}$ Since then, panel data have been compiled by the World Bank for Nepal, Rwanda, Uganda, Kenya and Tanzania, but have not yet been added to our dataset.

${ }^{6}$ Collier and Hoeffler (2004) illustrate the higher than normal effectiveness of aid in post-conflict societies.

${ }^{7}$ For example, the growth rate of sales covers four years for Botswana and Mali in period 1, Brazil, Pakistan, Senegal, South Africa and Zambia in period 2. It is calculated over two years for Niger in period 1.
} 
- FOREIGN ${ }_{i, k, j, t}$ : Dummy variable which is equal to one when part of (or all) the firm is owned by foreign individual or company.

- $\mathrm{STATE}_{i, k, j, t}$ : Dummy variable which is equal to one when part of (or all) the firm is owned by the State.

\subsection{Country-level variables}

Country-level variables are averaged over the period on which the growth of firms' sales is computed for each country. Following Beck et al. (2005) and Harrison et al. (2013), we control for the level of development using the logarithm of income per capita, the size of the country using the logarithm of the population, and the macroeconomic growth rate of the country. We also control for the quality of economic institutions using an indicator of control of corruption:

- GDP GROWTH ${ }_{j, t-3}$ : Growth rate of country $j$, lagged one period.

- $\mathrm{INCOME}_{j, t-3}$ : Logarithm of income per capita, lagged one period.

- POPULATION ${ }_{j, t}$ : Logarithm of population of country $j$ in year $t$.

- CORRUPTION ${ }_{j, t}$ : Indicator of the control of corruption. It ranges from approximately -2.5 (weak) to 2.5 (strong) control of corruption (Worldwide Governance Indicators, Kaufmann et al. (2011)).

Finally, we include aid, $\mathrm{ODA}_{j, t}$, in our estimations. Aid data are from the OECD-DAC, when aggregated, but from the OECD-CRS (country reporting system) when disaggregated at the sector level. Aid is measured in percent of GDP. Table 1 presents basic summary statistics for our sample of firms.

\subsection{Identification strategy for the impact of aid}

Equation 1 is estimated using the fixed-effect estimator. This allows us to control for firm-level time-invariant heterogeneity. To this fixed-effect setting we add industry $\mathrm{x}$ time dummies in order to also control for industry time-varying heterogeneity. Finally the standard errors are clustered at the country level.

Endogeneity concerns are largely attenuated by the fact that foreign aid is measured at the country level while the outcome, sales growth, is measured at the firm level. Moreover, our framework allows us to account for part of observable heterogeneity - using a large set of control variables both at the firm and country level - and for unobservable heterogeneity - using firms fixed-effects and industry-year dummies. 
Table 1: Summary statistics.

\begin{tabular}{|c|c|c|c|c|c|c|c|}
\hline Variables & & $\mathbf{N}$ & mean & median & sd & $\min$ & $\max$ \\
\hline \multicolumn{8}{|c|}{ Firm's characteristics } \\
\hline $\begin{array}{l}\operatorname{GROWTH}_{i, k, j, t} \\
\operatorname{SALES}_{i, k, j, t-3} \\
\text { STATE }_{i, k, j, t} \\
\text { FOREIGN }_{i, k, j, t} \\
\text { EXPORTS }_{i, k, j, t} \\
\text { POWER }_{i, k, j, t} \\
\text { ELECTRICITY_d }_{i, k, j, t} \\
\text { TRANSPORT_m }_{i, k, j, t} \\
\text { TRANSPORT_d }_{i, k, j, t} \\
\text { UNDER_UTILIZATION }_{i, k, j, t}\end{array}$ & $\begin{array}{r}\text { logarithm } \\
\text { dummy } \\
\text { dummy } \\
\text { dummy } \\
\text { dummy } \\
\text { dummy } \\
\text { dummy } \\
\text { dummy } \\
\text { dummy }\end{array}$ & $\begin{array}{l}9,970 \\
9,970 \\
9,970 \\
9,970 \\
9,970 \\
9,630 \\
9,940 \\
8,151 \\
9,876 \\
7,051\end{array}$ & $\begin{array}{r}7.71 \\
13.74 \\
0.01 \\
0.12 \\
0.34 \\
0.63 \\
0.56 \\
0.02 \\
0.41 \\
0.87\end{array}$ & $\begin{array}{r}3.08 \\
13.52 \\
0.00 \\
0.00 \\
0.00 \\
1.00 \\
1.00 \\
0.00 \\
0.00 \\
1.00\end{array}$ & $\begin{array}{r}35.05 \\
2.69 \\
0.08 \\
0.33 \\
0.47 \\
0.48 \\
0.50 \\
0.13 \\
0.49 \\
0.33\end{array}$ & $\begin{array}{r}-99.65 \\
5.23 \\
0.00 \\
0.00 \\
0.00 \\
0.00 \\
0.00 \\
0.00 \\
0.00 \\
0.00\end{array}$ & $\begin{array}{r}859.31 \\
28.81 \\
1.00 \\
1.00 \\
1.00 \\
1.00 \\
1.00 \\
1.00 \\
1.00 \\
1.00\end{array}$ \\
\hline \multicolumn{8}{|c|}{ Country variables $^{a}$} \\
\hline \multicolumn{8}{|c|}{ Macroeconomic situation variables } \\
\hline $\begin{array}{l}\text { INCOME }_{j, t-3} \\
\text { POPULATION }_{j, t} \\
\text { GDP GROWTH }_{j, t-3} \\
\text { CORRUPTION }_{j, t}\end{array}$ & $\begin{array}{l}\text { logarithm } \\
\text { logarithm }\end{array}$ & $\begin{array}{l}58 \\
58 \\
58 \\
58\end{array}$ & $\begin{array}{r}7.40 \\
16.53 \\
-1.28 \\
-0.32\end{array}$ & $\begin{array}{r}7.46 \\
16.43 \\
1.80 \\
-0.44\end{array}$ & $\begin{array}{l}1.15 \\
1.32 \\
8.41 \\
0.66\end{array}$ & $\begin{array}{r}5.27 \\
13.05 \\
-34.74 \\
-1.44\end{array}$ & $\begin{array}{r}9.51 \\
19.05 \\
10.08 \\
1.38\end{array}$ \\
\hline \multicolumn{8}{|c|}{ Aid variables } \\
\hline $\begin{array}{l}\text { ODA }_{j, t} \text { (net) } \\
\text { ODA }_{j, t} \text { (gross) } \\
\text { PRODUCTION }_{j, t} \text { (gross) } \\
\text { ENERGY }_{j, t} \text { (gross) } \\
\text { TRANSPORT GEOLOC }_{j, r, t} \text { (gross) } \\
\text { TRANSPORT NOT GEOLOC }_{j, t} \text { (gross) }\end{array}$ & $\begin{array}{l}\text { \%GDP } \\
\text { \%GDP } \\
\text { \%GDP } \\
\text { \%GDP } \\
\text { \%GDP } \\
\text { \%GDP }\end{array}$ & $\begin{array}{l}58 \\
58 \\
58 \\
58 \\
58 \\
58\end{array}$ & $\begin{array}{l}5.17 \\
7.45 \\
0.45 \\
0.05 \\
0.02 \\
0.28\end{array}$ & $\begin{array}{l}1.24 \\
1.66 \\
0.09 \\
0.01 \\
0.00 \\
0.07\end{array}$ & $\begin{array}{r}6.60 \\
10.74 \\
0.65 \\
0.09 \\
0.07 \\
0.44\end{array}$ & $\begin{array}{r}-0.10 \\
0.02 \\
0.00 \\
0.00 \\
0.00 \\
0.00\end{array}$ & $\begin{array}{r}21.73 \\
57.12 \\
2.76 \\
0.42 \\
0.48 \\
2.42\end{array}$ \\
\hline \multicolumn{8}{|c|}{ Infrastructure variables } \\
\hline $\begin{array}{l}\text { ELECTRICITY }_{j, t} \\
\operatorname{RAIL}_{j, t} \\
\operatorname{ROAD}_{j, t} \\
\operatorname{ROAD}_{j, t-1}\end{array}$ & $\begin{array}{l}\text { logarithm } \\
\text { logarithm }\end{array}$ & $\begin{array}{l}48 \\
33 \\
49 \\
54 \\
\end{array}$ & $\begin{array}{l}6.77 \\
8.06 \\
3.92 \\
3.87 \\
\end{array}$ & $\begin{array}{l}6.74 \\
7.69 \\
2.23 \\
2.26 \\
\end{array}$ & $\begin{array}{l}0.92 \\
1.35 \\
4.27 \\
4.74 \\
\end{array}$ & $\begin{array}{l}4.82 \\
5.82 \\
0.28 \\
0.06\end{array}$ & $\begin{array}{r}8.45 \\
10.48 \\
18.69 \\
23.11 \\
\end{array}$ \\
\hline
\end{tabular}

${ }^{a}$ Number of observations at the country-level.

However, the estimated correlation between foreign aid and firms' growth could still be biased through mainly one remaining endogeneity channel: the existence of time-varying unobservable heterogeneity. Firms that are in countries which receive higher amounts of aid may well have unobservable time-varying characteristics correlated with their growth rates. To account for this issue, we rely on an instrumentation procedure based on 'supply-side' determinants of aid allocation in the tradition of Tavares (2003) and Rajan 
and Subramanian (2008). More specifically, we find a source of exogenous variation of aid in changes in donors' economic environment, weighted by cultural and historic proximity between donors and receiving countries. More aid-prone donor environment is captured using the total amount of fiscal revenue (as a share of donors' GDP), FISCAL $_{j, t}$. Our instrument is then the weighted average of $\mathrm{FISCAL}_{j, t}$ for the $24 \mathrm{CAD}$ donors. We use two different variables to calculate the weighted sum of $\mathrm{FISCAL}_{j, t}:$ (1) either a dummy for whether the donor and the receiving country have the same religion - cultural distance ; or (2) a dummy for whether the receiving country is a former colony of the donor country - historic distance. We end up with two instruments for aid:

$$
\begin{gathered}
F_{I S C A L_{j, t} \times R E L I G I O N_{i, j}}=\Sigma_{j=1}^{24} F_{S C A L_{j, t}} \times R E L I G I O N_{i, j} \\
F I S C A L_{j, t} \times C O L O N Y i, j=\Sigma_{j=1}^{24} F_{I S C A L_{j, t}} \times C O L O N Y i, j
\end{gathered}
$$

\section{The impact of aid on firms growth}

\subsection{Benchmark results}

Before turning to our core results, we look at the results when the OLS estimator is used. In this case, Equation 1 is estimated without the firms fixed-effects $\left(\mu_{i}\right)$, but including country dummies and industry $\mathrm{x}$ year dummies. The standard errors are clustered at the firm level. The results are presented in Table 2 .

Using the OLS estimator, we do not need to restrict ourselves to the 5,640 firms for which we have panel data. Column (1) shows the results when all 20,732 firms are used. Then Column (2) shows the same estimation on the sample of firms for which we have two points in time. Finally, Column (3) shows the results when aid is instrumented. In all three estimations, the coefficient of $\operatorname{SALES}_{i, k, j, t-3}$ suggests a catching up effect: firms with lower levels of sales in $t$-3 tend to have higher growth rates in $t$ than firms that already sale a lot. $\mathrm{STATE}_{i, k, j, t}$ is never significant, suggesting that when firms are owned or partly owned by the state, their growth rate is not significantly different. FOREIGN ${ }_{i, k, j, t}$ and $\operatorname{EXPORTS}_{i, k, j, t}$ both have positive and significant coefficients suggesting that outward-looking firms and firms which are foreignly owned have a higher growth rate. Turning to the country-level variables, Table 2 shows that the level of development is positively correlated with firms growth: lagged income per capita has a positive and significant coefficient, which may proxy for the fact that higher income countries have a better business environment. The size of the population is also displaying a positive correlation with firms' growth, which reflects the fact that the 
size of the market is larger in bigger countries. GDP GROWTH $_{j, t-3}$ is not significant in OLS estimations. Finally, countries with a better control of corruption tend to have more performing firms.

Turning to the correlation of foreign aid with firms growth, regressions (1) to (3) show a positive and significant coefficient for aid, suggesting that a one percentage point increase in the share of aid in GDP would induce an increase in sales growth of around 1.2 percentage point.

The instruments used for aid in regression (3) seem to perform fairly well. They both have a significant coefficient in the first-step regression, with the expected sign. The Sargan over-identification test and the under-identification test are satisfactory.

Columns (4) to (6) display the results when firms fixed-effects are accounted for. Country dummies are now dropped and the standard errors are clustered at the country-level. When enterprises fixed-effects are introduced, some of the firm-level variables have to be abandoned. This is the case of $\mathrm{STATE}_{i, k, j, t}$ and FOREIGN $_{i, k, j, t}$ which do not sufficiently vary through time. Only 21 firms have a switch in $\mathrm{STATE}_{i, k, j, t}$ ( $0.42 \%$ of the observations) from period one to period two ; and 206 firms have a switch in FOREIGN Fi,k,j,t (4.13\% of the observations). EXPORTS ${ }_{i, k, j, t}$ is kept in the estimation because almost $10 \%$ of the firms (920) switched from no exports to exporting (or the reverse) between period one and two.

The results of regression (4) are very similar to those obtained in OLS. The only difference is that the country's GDP growth rate si now significantly and positively correlated with firms growth. The coefficient for aid is slightly higher than in the OLS estimation, but very close to the TSLS coefficient for aid in regressions (3). It implies that firms in countries where aid is increased by one percentage point would see their growth increased by around 1.7 percentage point. While this may seem a lot, the impact of aid on firms growth has to be related to the average growth rate of the firms in our sample. Section 4.3 below provides evidence that the impact of aid on firms growth found in our regressions falls in the same range as the effect of aid on aggregate growth rate. 
Table 2: Benchmark estimations of the impact of aid on firms' growth.

\begin{tabular}{|c|c|c|c|c|c|}
\hline $\begin{array}{l}\text { Dependent variable: } \\
\text { Sales growth }\end{array}$ & $\begin{array}{l}1) \\
\text { OLS }\end{array}$ & $\begin{array}{l}(2) \\
\text { OLS }\end{array}$ & $\begin{array}{c}(3) \\
\text { TSLS }\end{array}$ & $\begin{array}{l}(4) \\
\text { FE }\end{array}$ & $\begin{array}{c}(5) \\
\text { TSLS-FE }\end{array}$ \\
\hline $\operatorname{SALES}_{i, k, j, t-3}$ & $\begin{array}{c}-4.008^{* * *} \\
(0.169)\end{array}$ & $\begin{array}{c}-4.540^{* * *} \\
(0.278)\end{array}$ & $\begin{array}{c}-4.540^{* * *} \\
(0.276)\end{array}$ & $\begin{array}{c}-11.16^{* * *} \\
(2.088)\end{array}$ & $\begin{array}{c}-11.18^{* * *} \\
(2.046)\end{array}$ \\
\hline $\operatorname{STATE}_{i, k, j, t}$ & $\begin{array}{c}4.389 \\
(2.976)\end{array}$ & $\begin{array}{c}6.188 \\
(6.592)\end{array}$ & $\begin{array}{c}6.174 \\
(6.550)\end{array}$ & & \\
\hline FOREIGN $_{i, k, j, t}$ & $\begin{array}{c}6.137^{* * *} \\
(0.655)\end{array}$ & $\begin{array}{c}6.523^{* * *} \\
(1.088)\end{array}$ & $\begin{array}{c}6.524^{* * *} \\
(1.081)\end{array}$ & & \\
\hline $\operatorname{EXPORTS}_{i, k, j, t}$ & $\begin{array}{c}6.828^{* * *} \\
(0.513)\end{array}$ & $\begin{array}{c}6.563^{* * *} \\
(0.817)\end{array}$ & $\begin{array}{c}6.563^{* * *} \\
(0.813)\end{array}$ & $\begin{array}{c}5.216^{* * *} \\
(1.423)\end{array}$ & $\begin{array}{c}5.260^{* * *} \\
(1.373)\end{array}$ \\
\hline $\operatorname{INCOME}_{j, t-3}$ & $\begin{array}{c}23.55^{* * *} \\
(2.605)\end{array}$ & $\begin{array}{c}31.03^{* * *} \\
(5.199)\end{array}$ & $\begin{array}{c}30.94^{* * *} \\
(5.151)\end{array}$ & $\begin{array}{c}57.56^{* * *} \\
(18.56)\end{array}$ & $\begin{array}{c}58.04^{* * *} \\
(18.52)\end{array}$ \\
\hline $\mathrm{GDP}^{\mathrm{GROWTH}_{j, t-3}}$ & $\begin{array}{c}0.0132 \\
(0.0783)\end{array}$ & $\begin{array}{c}0.276 \\
(0.184)\end{array}$ & $\begin{array}{c}0.259 \\
(0.173)\end{array}$ & $\begin{array}{l}1.080^{*} \\
(0.623)\end{array}$ & $\begin{array}{l}1.037^{*} \\
(0.584)\end{array}$ \\
\hline CORRUPTION $_{j, t}$ & $\begin{array}{c}52.06^{* * *} \\
(4.568)\end{array}$ & $\begin{array}{c}60.03^{* * *} \\
(7.511)\end{array}$ & $\begin{array}{c}60.77^{* * *} \\
(7.083)\end{array}$ & $\begin{array}{c}69.08^{* * *} \\
(12.21)\end{array}$ & $\begin{array}{c}74.32^{* * *} \\
(13.40)\end{array}$ \\
\hline POPULATION $_{j, t}$ & $\begin{array}{c}138.0 * * * \\
(28.91)\end{array}$ & $\begin{array}{c}228.6^{* * *} \\
(44.48)\end{array}$ & $\begin{array}{c}219.2^{* * *} \\
(42.20)\end{array}$ & $\begin{array}{c}288.0^{* *} \\
(114.4)\end{array}$ & $\begin{array}{c}263.6^{* * *} \\
(100.6)\end{array}$ \\
\hline $\mathrm{ODA}_{j, t}, \% \mathrm{GDP}$ & $\begin{array}{c}1.220^{* * *} \\
(0.407)\end{array}$ & $\begin{array}{l}1.346^{* *} \\
(0.568)\end{array}$ & $\begin{array}{l}1.655^{* *} \\
(0.782)\end{array}$ & $\begin{array}{l}1.770^{* *} \\
(0.641)\end{array}$ & $\begin{array}{c}3.423^{* *} \\
(1.429)\end{array}$ \\
\hline \multicolumn{6}{|l|}{ First-step results } \\
\hline $\begin{array}{l}\operatorname{FISCAL}_{j, t} \times \operatorname{COLONY}_{i, j} \\
\text { FISCAL }_{j, t} \times \operatorname{RELIGION}_{i, j}\end{array}$ & & & $\begin{array}{l}1.832^{* * *} \\
(0.0545) \\
0.195^{* * *} \\
(0.0179)\end{array}$ & & $\begin{array}{c}1.745^{* * *} \\
(0.521) \\
0.182 \\
(0.139)\end{array}$ \\
\hline Observations & 25,062 & 9,970 & 9,970 & 9,970 & 8,660 \\
\hline R-squared & 0.126 & 0.134 & 0.134 & 0.244 & 0.243 \\
\hline Number of firms & 20,732 & 5,640 & 5,640 & 5,640 & 4,330 \\
\hline Firms FE & no & no & no & yes & yes \\
\hline Industry x Year dummies & yes & yes & yes & yes & yes \\
\hline Level of se clustering & firm & firm & firm & country & country \\
\hline Country dummies & yes & yes & yes & no & no \\
\hline Sargan (p-value) & & & 0.815 & & 0.212 \\
\hline F-test (stat) & & & 769.63 & & 9.45 \\
\hline Under id. test ( $p$-value) & & & 0.000 & & 0.000 \\
\hline
\end{tabular}

Columns (1) and (2) are estimated using the OLS estimator, with country and industry $\mathrm{x}$ year dummies and robust standard errors clustered at the firm level. Columns (3) is estimated using the TSLS estimator, with country and industry $\mathrm{x}$ year dummies and robust standard errors clustered at the firm level. Columns (4) and (6) are estimated using the within estimator, with firms fixed-effects, industry $\mathrm{x}$ year dummies and robust clustered standard errors at the country level. Column (5) is estimated using the TSLS estimator with firms fixed effects, industry $\mathrm{x}$ year dummies and robust clustered standard errors at the country level. ${ }^{* * *} \mathrm{p}<0.01,{ }^{* *} \mathrm{p}<0.05,{ }^{*} \mathrm{p}<0.1$. 
In Column (5), the two-stage least squares estimation when fixed-effects are accounted for are also very similar to the previous result. The Sargan over-identification test, the F-test and the under-identification test all provide satisfactory results. One of the two instruments used loses its significance $\left(\mathrm{FISCAL}_{j, t} \mathrm{x}\right.$ $\left.\mathrm{COLONY}_{i, j}\right)$, but we keep it in order to be able to display the over-identification test. The results are unaltered when this instrument is dropped. ${ }^{8}$ The only concern is that the coefficient of aid is now almost doubled. However, given the size of the standard deviations, the coefficients of Columns (4) and (5) are not significantly different. In regression (5), 1,310 enterprises are dropped because they only have one observation instead of two. The panel is therefore balanced, compared to the previous regressions in which it is unbalanced. The loss of 1,310 enterprises is a fairly high price to pay for having a balanced panel and the remaining of our analysis will therefore rely on the complete unbalanced panel.

\subsection{Robustness checks}

\subsubsection{Endogeneity of the firm-level controls}

In what follows we present various robustness checks for the benchmark results. First, we address the issue of the potential endogeneity of the firm-level control variables. As is common in the literature on firms growth, the firm-level variables can be re-aggregated on cells at the industry-region-size level in each country (see Harrison et al. (2013)). We apply this method to $\operatorname{EXPORTS}_{i, k, j, t}, \mathrm{FOREIGN}_{i, k, j, t}$ and $\mathrm{STATE}_{i, k, j, t}$. On the sample of firms in panel, some of the cells are likely to be very small. When the cells include less than 5 firms, we set the aggregation level at the industry-region level. For those cells which remain too small (less than five firms), we set the aggregation level at the industry level. The three following variables are computed:

- sh_EXPORTS ${ }_{i, k, j, t}$ : Share of firms in the industry-region-size cell that are exporting part or all its sales, either directly or indirectly.

- sh_FOREIGN ${ }_{i, k, j, t}$ : Share of firms in the industry-region-size cell that are partly or fully owned by foreign individual or company.

- sh_STATE ${ }_{i, k, j, t}$ : Share of firms in the industry-region-size cell that are partly or fully owned by the State.

Table 3 displays the results when those three firm-level controls are replaced by their aggregation on industry-region-size. It highlights that the coefficient for foreign aid is unaltered by this change. Moreover,

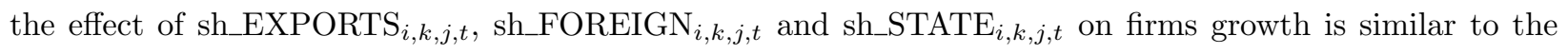
effect of $\operatorname{EXPORTS}_{i, k, j, t}$, FOREIGN $_{i, k, j, t}$ and $\operatorname{STATE}_{i, k, j, t}$.

\footnotetext{
${ }^{8}$ The coefficient of foreign aid is significant at the $10 \%$ level and equal to 3.34 .
} 
Table 3: Measuring firm-level control variables on industry-region-size cells.

\begin{tabular}{|c|c|c|c|c|c|}
\hline $\begin{array}{l}\text { Dependent variable: } \\
\text { Sales growth }\end{array}$ & $\begin{array}{l}(1) \\
\text { OLS }\end{array}$ & $\begin{array}{l}(2) \\
\text { OLS }\end{array}$ & $\begin{array}{c}(3) \\
\text { TSLS }\end{array}$ & $\begin{array}{l}(4) \\
\mathrm{FE}\end{array}$ & $\begin{array}{c}(5) \\
\text { TSLS-FE }\end{array}$ \\
\hline $\operatorname{SALES}_{i, k, j, t-3}$ & $\begin{array}{c}-4.228^{* * *} \\
(0.172)\end{array}$ & $\begin{array}{c}-4.656^{* * *} \\
(0.279)\end{array}$ & $\begin{array}{c}-4.658^{* * *} \\
(0.277)\end{array}$ & $\begin{array}{c}-11.13^{* * *} \\
(2.083)\end{array}$ & $\begin{array}{c}-11.16^{* * *} \\
(2.043))\end{array}$ \\
\hline sh_STATE ${ }_{i, k, j, t}$, indus-region-size & $\begin{array}{l}19.19^{* *} \\
(8.748)\end{array}$ & $\begin{array}{c}10.87 \\
(15.25)\end{array}$ & $\begin{array}{l}11.05 \\
(15.13)\end{array}$ & & \\
\hline sh_FOREIGN ${ }_{i, k, j, t}$, indus-region-size & $\begin{array}{c}15.00^{* * *} \\
(1.693)\end{array}$ & $\begin{array}{c}16.65^{* * *} \\
(2.639)\end{array}$ & $\begin{array}{c}16.64^{* * *} \\
(2.622)\end{array}$ & & \\
\hline $\operatorname{sh} \_$EXPORTS $_{i, k, j, t}$, indus-region-size & $\begin{array}{c}14.53^{* * *} \\
(1.083)\end{array}$ & $\begin{array}{c}13.22^{* * *} \\
(1.705)\end{array}$ & $\begin{array}{c}13.23^{* * *} \\
(1.696)\end{array}$ & $\begin{array}{c}7.039 \\
(4.763)\end{array}$ & $\begin{array}{c}7.264 \\
(4.621)\end{array}$ \\
\hline $\mathrm{INCOME}_{j, t-3}$ & $\begin{array}{c}23.16^{* * *} \\
(2.601)\end{array}$ & $\begin{array}{c}29.95^{* * *} \\
(5.139)\end{array}$ & $\begin{array}{c}29.90^{* * *} \\
(5.101)\end{array}$ & $\begin{array}{c}57.09^{* * *} \\
(18.46)\end{array}$ & $\begin{array}{c}57.57^{* * *} \\
(18.41)\end{array}$ \\
\hline $\mathrm{GDP}_{\text {GROWTH}} j, t-3$ & $\begin{array}{c}0.0410 \\
(0.0779)\end{array}$ & $\begin{array}{c}0.280 \\
(0.182)\end{array}$ & $\begin{array}{c}0.261 \\
(0.173)\end{array}$ & $\begin{array}{l}1.073^{*} \\
(0.615)\end{array}$ & $\begin{array}{l}1.030^{*} \\
(0.576)\end{array}$ \\
\hline CORRUPTION $_{j, t}$ & $\begin{array}{c}51.17^{* * *} \\
(4.583)\end{array}$ & $\begin{array}{c}59.63^{* * *} \\
(7.573)\end{array}$ & $\begin{array}{c}61.19^{* * *} \\
(7.129)\end{array}$ & $\begin{array}{c}68.53^{* * *} \\
(12.17)\end{array}$ & $\begin{array}{c}73.76^{* * *} \\
(13.32)\end{array}$ \\
\hline POPULATION $_{j, t}$ & $\begin{array}{c}142.6^{* * *} \\
(28.86)\end{array}$ & $\begin{array}{c}230.3^{* * *} \\
(44.33)\end{array}$ & $\begin{array}{c}222.9^{* * *} \\
(43.62)\end{array}$ & $\begin{array}{c}287.0^{* *} \\
(113.0)\end{array}$ & $\begin{array}{c}262.7^{* * * *} \\
(99.54)\end{array}$ \\
\hline $\mathrm{ODA}_{j, t}, \% \mathrm{GDP}$ & $\begin{array}{c}1.114^{* * *} \\
(0.407)\end{array}$ & $\begin{array}{l}1.335^{* *} \\
(0.569)\end{array}$ & $\begin{array}{l}1.823^{* *} \\
(0.782)\end{array}$ & $\begin{array}{c}1.780^{* * * *} \\
(0.641)\end{array}$ & $\begin{array}{c}3.431^{* *} \\
(1.390)\end{array}$ \\
\hline \multicolumn{6}{|l|}{ First-step results } \\
\hline $\mathrm{FISCAL}_{j, t} \times \mathrm{COLONY}_{i, j}$ & & & $\begin{array}{l}1.832^{* * *} \\
(0.0545)\end{array}$ & & $\begin{array}{c}1.744^{* * *} \\
(0.521)\end{array}$ \\
\hline FISCAL $_{j, t} \times$ RELIGION $_{i, j}$ & & & $\begin{array}{l}0.195^{* * *} \\
(0.0178)\end{array}$ & & $\begin{array}{c}0.182 \\
(0.139)\end{array}$ \\
\hline Observations & 25,062 & 9,970 & 9,970 & 9,970 & 8,660 \\
\hline R-squared & 0.128 & 0.135 & 0.135 & 0.243 & 0.242 \\
\hline Number of firms & 20,732 & 5,640 & 5,640 & 5,640 & 4,330 \\
\hline Firms FE & no & no & no & yes & yes \\
\hline Industry x Year dummies & yes & yes & yes & yes & yes \\
\hline Level of se clustering & firm & firm & firm & country & country \\
\hline Country dummies & yes & yes & yes & no & no \\
\hline Sargan (p-value) & & & 0.858 & & 0.529 \\
\hline F-test (stat) & & & 769.32 & & 9.48 \\
\hline Under id. test (p-value) & & & 0.000 & & 0.234 \\
\hline
\end{tabular}

Columns (1) and (2) are estimated using the OLS estimator, with country and industry $\mathrm{x}$ year dummies and robust standard errors clustered at the firm level. Columns (3) is estimated using the TSLS estimator, with country and industry x year dummies and robust standard errors clustered at the firm level. Columns (4) and (6) are estimated using the within estimator, with firms fixed-effects, industry x year dummies and robust clustered standard errors at the country level. Column (5) is estimated using the TSLS estimator with firms fixed effects, industry $\mathrm{x}$ year dummies and robust clustered standard errors at the country level. ${ }^{* * *} \mathrm{p}<0.01,{ }^{* *} \mathrm{p}<0.05,{ }^{*} \mathrm{p}<0.1$. 


\subsubsection{Net versus Gross disbursements}

The second robustness check consists in examining the stability of the results when using aid gross disbursements instead of aid net disbursements, which are net of repayments. The correlation between net and gross disbursements is quite high $(0.95$, p-value $=0.000)$, and we would expect both variables to have a similar impact on firms growth. However, they do not measure the same thing: gross disbursements are a good proxy for the level of investments of donors in receiving countries while net disbursements are a good proxy for the financing capacity of the receiving countries. This robustness check is particularly important in our analysis. As discussed below, in order to understand the mechanisms through which aid flows influence firms growth, we will be looking at the impact of various sector aid variables on the constraints they face. Those sector aid variables are only available for gross disbursement and the remaining of our analysis will therefore switch from using net disbursements to using gross disbursements.

Table 4 reproduces our benchmark results with gross disbursements and underlines the stability of the results to changing the definition of aid. Column (4) of Table 4 reproduces our core estimation with gross disbursements. It suggests that a one percent increase in aid gross disbursements would lead to an increase of around 1.5 percentage point of the growth rate of enterprises in the receiving countries.

The results in Column (5) suggest that the instruments perform more poorly for gross disbursements than for net disbursements. As for net disbursements, the instrument $\operatorname{FISCAL}_{j, t} \times$ RELIGION $_{i, j}$ is not significant in the first-step, but it implies a drop in the F-test which gets to the low value of 2.7. However, when we exclude this instrument, and only keep $\operatorname{FISCAL}_{j, t} \times \mathrm{COLONY}_{i, j}$, the first-step results are better. ${ }^{9}$ The correlation of $\mathrm{FISCAL}_{j, t} \times \mathrm{COLONY}_{i, j}$ with gross disbursements in the first-step is 3.935 (p-value = $0.009)$ and the first-step F-test is 7.94 (p-value $=0.009)$. The impact of aid on growth in the second-step is virtually unchanged, the coefficient being 2.064 ( $\mathrm{p}$-value $=0.027)$.

\footnotetext{
${ }^{9}$ In this case we are no longer able to compute a Sargan over-identification test.
} 
Table 4: Replacing net aid disbursements with gross aid disbursements.

\begin{tabular}{|c|c|c|c|c|c|}
\hline $\begin{array}{l}\text { Dependent variable: } \\
\text { Sales growth }\end{array}$ & $\begin{array}{l}(1) \\
\text { OLS }\end{array}$ & $\begin{array}{l}(2) \\
\text { OLS }\end{array}$ & $\begin{array}{c}(3) \\
\text { TSLS }\end{array}$ & $\begin{array}{l}(4) \\
\text { FE }\end{array}$ & $\begin{array}{c}(5) \\
\text { TSLS-FE }\end{array}$ \\
\hline $\mathrm{ODA}_{j, t}$ gross, $\% \mathrm{GDP}$ & $\begin{array}{c}0.826^{* * *} \\
(0.204)\end{array}$ & $\begin{array}{c}0.943^{* * *} \\
(0.267)\end{array}$ & $\begin{array}{c}0.836^{* *} \\
(0.387)\end{array}$ & $\begin{array}{l}1.501^{* *} \\
(0.555)\end{array}$ & $\begin{array}{l}1.665^{* *} \\
(0.649)\end{array}$ \\
\hline \multicolumn{6}{|l|}{ First-step results } \\
\hline $\operatorname{FISCAL~}_{j, t} \times \mathrm{COLONY}_{i, j}$ & & & $\begin{array}{c}3.582^{* * *} \\
(0.164) \\
0.413^{* * *} \\
(0.0641)\end{array}$ & & $\begin{array}{c}3.108^{*} \\
(1.568) \\
0.453 \\
(0.468)\end{array}$ \\
\hline Observations & 25,062 & 9,970 & 9,970 & 9,970 & 8,660 \\
\hline R-squared & 0.126 & 0.135 & 0.135 & 0.247 & 0.247 \\
\hline Number of firms & 20,732 & 5,640 & 5,640 & 5,640 & 4,330 \\
\hline Firms FE & no & no & no & yes & yes \\
\hline Countries FE & yes & yes & yes & no & no \\
\hline Industry x Year dummies & yes & yes & yes & yes & yes \\
\hline Level of se clustering & firm & firm & firm & country & country \\
\hline Firm-level controls & yes & yes & yes & yes & yes \\
\hline Country-level controls & yes & yes & yes & yes & yes \\
\hline Sargan (p-value) & & & 0.780 & & 0.124 \\
\hline F-test (stat) & & & 275.26 & & $2.7(\mathrm{p}=0.084)$ \\
\hline Under-identification (p-value) & & & 0.000 & & 0.059 \\
\hline
\end{tabular}

Columns (1) and (2) are estimated using the OLS estimator, with country and industry x year dummies and robust standard errors clustered at the firm level. Columns (3) is estimated using the TSLS estimator, with country and industry $\mathrm{x}$ year dummies and robust standard errors clustered at the firm level. Column (4) is estimated using the within estimator, with firms fixed-effects, industry x year dummies and robust clustered standard errors at the country level. Column (5) is estimated using the TSLS estimator with firms fixed effects, industry x year dummies and robust clustered standard errors at the country level. $* * * \mathrm{p}<0.01$, ${ }^{* *} \mathrm{p}<0.05, * \mathrm{p}<0.1$.

\subsubsection{Specification tests}

We next turn to specification tests. In Table 5 we introduce sequentially various firm-level and countrylevel characteristics in the benchmark regressions of Columns 4 of Tables 2 and 4 . All regressions also include the same country and firm-level control variables as in the benchmark regression. In Columns (1) to (4) we introduce additional firm-level variables. The coefficient of aid - either measured in net or gross disbursements - is not altered by the introduction of FINPB (whether credit access is considered as a major obstacle), OVERDRAFT (whether the firm benefits from an overdraft facility), CORRPB (whether 
corruption is considered as a major obstacle) and SIZE (number of employees). ${ }^{10}$ In Columns (5) to (7) we include additional country-level characteristics, that if correlated with aid and firms performances may induce an omitted variable bias. It turns out that neither FDI (foreign direct investment as a percentage of GDP), nor REMIT (workers remittances as a percentage of GDP), nor POLITY (the polity score provided by POLITY IV) have a significant influence on our sample of firms growth performance. The coefficient of the aid variable is unchanged when these variables are introduced in the benchmark estimations.

Table 5: Specification tests.

\begin{tabular}{|c|c|c|c|c|c|c|c|}
\hline $\begin{array}{l}\text { Dependent: Sales growth } \\
\text { Fixed-effect estimations }\end{array}$ & $\begin{array}{l}\text { FINPB } \\
\quad(1)\end{array}$ & $\begin{array}{l}\text { OVERDRAFT } \\
(2)\end{array}$ & $\begin{array}{l}\text { CORRPB } \\
(3)\end{array}$ & $\begin{array}{l}\text { SIZE } \\
(4)\end{array}$ & $\begin{array}{l}\text { FDI } \\
(5)\end{array}$ & $\begin{array}{l}\text { REMIT } \\
(6)\end{array}$ & $\begin{array}{l}\text { POLITY } \\
(7)\end{array}$ \\
\hline $\mathrm{ODA}_{j, t}$ net, $\% \mathrm{GDP}$ & $\begin{array}{l}1.960^{* * *} \\
(0.496)\end{array}$ & $\begin{array}{l}1.025^{*} \\
(0.530)\end{array}$ & $\begin{array}{l}1.777^{* *} \\
(0.698)\end{array}$ & $\begin{array}{l}1.676^{* *} \\
(0.699)\end{array}$ & $\begin{array}{l}1.489^{*} \\
(0.823)\end{array}$ & $\begin{array}{l}2.088^{* *} \\
(0.876)\end{array}$ & $\begin{array}{l}1.931^{* *} \\
(0.792)\end{array}$ \\
\hline VARIABLE & $\begin{array}{l}-0.592 \\
(1.035)\end{array}$ & $\begin{array}{c}2.014 \\
(1.859)\end{array}$ & $\begin{array}{l}-0.541 \\
(0.850)\end{array}$ & $\begin{array}{c}0.006^{* * *} \\
(0.001)\end{array}$ & $\begin{array}{l}-0.709 \\
(1.460)\end{array}$ & $\begin{array}{c}0.275 \\
(1.772)\end{array}$ & $\begin{array}{l}-2.691 \\
(4.148)\end{array}$ \\
\hline $\mathrm{ODA}_{j, t}$ gross, $\% \mathrm{GDP}$ & $\begin{array}{c}1.780^{* * *} \\
(0.496)\end{array}$ & $\begin{array}{l}0.521^{*} \\
(0.278)\end{array}$ & $\begin{array}{c}1.533^{* * *} \\
(0.544)\end{array}$ & $\begin{array}{l}1.486^{* *} \\
(0.560)\end{array}$ & $\begin{array}{l}1.455^{* *} \\
(0.590)\end{array}$ & $\begin{array}{l}1.408^{* *} \\
(0.556)\end{array}$ & $\begin{array}{c}1.818^{* * *} \\
(0.626)\end{array}$ \\
\hline VARIABLE & $\begin{array}{l}-0.553 \\
(1.038)\end{array}$ & $\begin{array}{c}2.065 \\
(1.872)\end{array}$ & $\begin{array}{c}-0.379 \\
(0.799)\end{array}$ & $\begin{array}{c}0.006^{* * *} \\
(0.001)\end{array}$ & $\begin{array}{c}-0.839 \\
(1.246)\end{array}$ & $\begin{array}{l}-0.149 \\
(1.655)\end{array}$ & $\begin{array}{l}-4.772 \\
(4.373)\end{array}$ \\
\hline Observations & 9184 & 9388 & 9805 & 9949 & 9970 & 9923 & 9970 \\
\hline Firms FE & yes & yes & yes & yes & yes & yes & yes \\
\hline Industry $\mathrm{x}$ Year dummies & yes & yes & yes & yes & yes & yes & yes \\
\hline Level of se clustering & country & country & country & country & country & country & country \\
\hline Firm-level controls & yes & yes & yes & yes & yes & yes & yes \\
\hline Country-level controls & yes & yes & yes & yes & yes & yes & yes \\
\hline
\end{tabular}

Estimation using the within estimator, with firms fixed-effects, industry x year dummies and robust clustered standard errors at the country level. All estimations include country and firm-level control variables. FINPB is a dummy equal to one if the firm declares access to credit to be a major obstacle to its activity. OVERDRAFT is equal to one if the firm declares having an overdraft facility. CORRPB is equal to one if corruption is a major obstacle to firm activity. SIZE is the number of employees. FDI is the ratio of foreign direct investment in GDP. REMIT is the ratio of workers remittances in GDP. POLITY is the POLITY IV indicator $(-10,+10) .{ }^{* * *} \mathrm{p}<0.01,{ }^{* *} \mathrm{p}<0.05,{ }^{*} \mathrm{p}<0.1$.

\footnotetext{
${ }^{10}$ The impact of access to finance on firms exports is explored in Chauvet and Jacolin (2014).
} 


\subsubsection{Sample dependence}

We then explore the robustness of our results to changes in sample. Sample-dependence is an issue that is particularly acute in the aid effectiveness literature. Table 15 in Appendix 2 presents the results obtained for the fixed-effect benchmark estimation when each country is excluded one at the time. Column (1) presents the coefficient of net disbursements. Column (2) presents the coefficients of gross disbursements. Table 15 in Appendix 2 suggests that the coefficient of aid (net or gross) obtained in the fixed-effect estimations is unchanged by the exclusion of one country at the time.

As presented in Appendix 1, different numbers of firms have been surveyed in the countries of our sample. The number of observations spans from 96 (Niger) to 842 (Argentina). As our variable of interest, aid, is measured at the country level, this implies that some countries, those in which a larger number of firms was interviewed, are over-represented in our sample. In Table 6 we display the results when each country is given the same weight, by drawing randomly the same number of enterprises from each survey. In Columns (1) and (2) we draw randomly 40 firms for each country and then expend the number of firms to 70 (Columns (3) and (4)) and 100 (Columns (5) and (6)). As before, we use Columns (4) of Tables 2 and 4 as our benchmarks to run this exercise. The coefficients for aid - either measured as net or gross inflow - are very close to the coefficients of aid in Columns (4) of Tables 2 and 4.

Table 6: Random draw of firms.

\begin{tabular}{|c|c|c|c|c|c|c|}
\hline \multirow{2}{*}{$\begin{array}{l}\text { Dependent: Sales growth } \\
\text { Type of aid } \\
\text { Fixed-effect estimations }\end{array}$} & \multicolumn{2}{|c|}{40 firms } & \multicolumn{2}{|c|}{70 firms } & \multicolumn{2}{|c|}{100 firms } \\
\hline & $\begin{array}{l}\text { Net } \\
(1)\end{array}$ & $\begin{array}{c}\text { Gross } \\
(2) \\
\end{array}$ & $\begin{array}{l}\text { Net } \\
(3)\end{array}$ & $\begin{array}{c}\text { Gross } \\
(4) \\
\end{array}$ & $\begin{array}{l}\text { Net } \\
(5)\end{array}$ & $\begin{array}{c}\text { Gross } \\
(6) \\
\end{array}$ \\
\hline $\mathrm{ODA}_{j, t}, \% \mathrm{GDP}$ & $\begin{array}{c}2.474^{* * *} \\
(0.559)\end{array}$ & $\begin{array}{c}1.751^{* * *} \\
(0.318)\end{array}$ & $\begin{array}{c}2.019^{* * *} \\
(0.655)\end{array}$ & $\begin{array}{c}1.675^{* * *} \\
(0.445)\end{array}$ & $\begin{array}{c}1.776^{* * *} \\
(0.616)\end{array}$ & $\begin{array}{c}1.607^{* * *} \\
(0.486)\end{array}$ \\
\hline Observations & 2,302 & 2,302 & 3,750 & 3,750 & 4,758 & 4,758 \\
\hline R-squared & 0.285 & 0.294 & 0.245 & 0.252 & 0.226 & 0.232 \\
\hline Number of Firms & 1,151 & 1,151 & 1,875 & 1,875 & 2,379 & 2,379 \\
\hline Firms FE & yes & yes & yes & yes & yes & yes \\
\hline Industry x Year dummies & yes & yes & yes & yes & yes & yes \\
\hline Level of se clustering & country & country & country & country & country & country \\
\hline Firm-level controls & yes & yes & yes & yes & yes & yes \\
\hline Country-level controls & yes & yes & yes & yes & yes & yes \\
\hline
\end{tabular}

ODA is measured as a percentage of GDP, either in net flows or gross flows. Estimation using the within estimator, with firms fixed-effects, industry x year dummies and robust clustered standard errors at the country level. All estimations include country and firm-level control variables. ${ }^{* * *} \mathrm{p}<0.01,{ }^{* *} \mathrm{p}<0.05,{ }^{*} \mathrm{p}<0.1$. 


\subsubsection{Attrition}

World Bank Enterprise Surveys are sampled in a way as to be representative at the country level, with three levels of stratification: region, industry and size. However, the firms are representative for each round of survey; but the firms which were interviewed twice (two rounds) only represent one fourth of the total initial sample of firms. Obviously, there is no reason to believe that the firms that are interviewed twice are representative at the national level.

One related question is the issue of selection bias. If the firms that are interviewed twice are so because they are more likely to survive (better performance, specific activity, etc.) and if the probability to survive is somewhat related to how much aid is received in the country, then the estimated aid effect could be biased. There is no simple answer to this issue, as well as to the potential lack of representativeness of our sample.

In Table 7 we present simple mean-comparison tests of the growth rate of the firms, comparing those which survive in period two with those which do not. We compare the initial characteristics of these two groups, that is in period one. Table 7 suggests that the initial performance of the two groups of firms are not significantly different.

The remaining of Table 7 presents the same exercise, but comparing the firms that appear in period two to the firms that were already in the sample in period one. The growth rate of the two groups of firms seems to be significantly different, with the firms in panel displaying on average lower growth rates than the firms that appear in period 2 .

Table 7: Mean-comparison tests, by period.

\begin{tabular}{lcccc}
\hline \hline & Group 1 & Group 2 & & \\
& Firms which do not survive & Firms which survive & Difference & p-value \\
\hline \hline \multirow{2}{*}{ SALES GROWTH ${ }_{i, k, j, t}$} & 10.14 & 10.92 & -0.787 & 0.189 \\
Observations & 9074 & 4781 & & \\
\hline \hline & Firms which appear in period 2 & Firms which survive & Difference & p-value \\
\hline \hline & 5.92 & 4.75 & 1.182 & 0.052 \\
SALES GROWTH & & & \\
Observations & 8018 & 5189 & & \\
\hline \hline
\end{tabular}

In the upper part of the table, firms of group 1 and 2 are compared for period one only. In the lower part of the table firms are compared in period 2 only. 
Table 7 suggests that attrition may indeed bias our results and calls for further investigation. In Table 8, we first reproduce the results obtained on the sample of all firms, using the OLS estimator. Despite the absence of firm-fixed effects, the results are similar to those obtained in the benchmark estimations.

We then turn to re-aggregating all variables on cells at the industry-region-size. All information concerning the 25,062 observations in the database is now used. We estimate the average growth rate computed at the industry-region-size level as a function of cells characteristics (share of firms in the cell that are state-owned, or owned by foreign investors, or exporting), as well as of the country-level characteristics. We include cells fixed effects and control for a time trend. Columns (3) and (4) present the results. Despite the fact that the coefficients are very close to those of the benchmark estimations (and not statistically different), the coefficient for net disbursements is no longer significant. The coefficient for gross disbursements remains significant at the $10 \%$ level.

Table 8: Re-aggregating at the industry-region-size and industry-region level.

\begin{tabular}{|c|c|c|c|c|c|c|}
\hline \multirow{2}{*}{$\begin{array}{l}\text { Level } \\
\text { Type of aid }\end{array}$} & \multicolumn{2}{|c|}{ Firm } & \multicolumn{2}{|c|}{ Indus-region-size } & \multicolumn{2}{|c|}{ Indus-region } \\
\hline & $\begin{array}{l}\text { Net } \\
(1)\end{array}$ & $\begin{array}{c}\text { Gross } \\
(2)\end{array}$ & $\begin{array}{l}\text { Net } \\
(3)\end{array}$ & $\begin{array}{c}\text { Gross } \\
(4)\end{array}$ & $\begin{array}{l}\text { Net } \\
(5)\end{array}$ & $\begin{array}{c}\text { Gross } \\
(6)\end{array}$ \\
\hline $\mathrm{ODA}_{j, t}, \% \mathrm{GDP}$ & $\begin{array}{c}1.220^{* * *} \\
(0.407)\end{array}$ & $\begin{array}{c}0.826^{* * *} \\
(0.204)\end{array}$ & $\begin{array}{c}0.944 \\
(0.685)\end{array}$ & $\begin{array}{c}1.615^{* * *} \\
(0.349)\end{array}$ & $\begin{array}{l}1.299^{*} \\
(0.735)\end{array}$ & $\begin{array}{c}1.416^{* * *} \\
(0.375)\end{array}$ \\
\hline Observations & 25,062 & 25,062 & 3,135 & 3,135 & 1,910 & 1,910 \\
\hline Number of firms & 20,732 & 20,732 & 1,977 & 1,977 & 1,165 & 1,165 \\
\hline Country fixed-effects & yes & yes & no & no & no & no \\
\hline Industry x Year dummies & yes & yes & no & no & no & no \\
\hline Cell FE & no & no & yes & yes & yes & yes \\
\hline Year dummies & no & no & yes & yes & yes & yes \\
\hline Level of se clustering & firm & firm & cells & cells & cells & cells \\
\hline Firm-level controls & yes & yes & yes & yes & yes & yes \\
\hline Country-level controls & yes & yes & yes & yes & yes & yes \\
\hline
\end{tabular}

ODA is measured as a percentage of GDP, either in net flows or gross flows. In Columns (1) and (2) OLS estimations. In columns (3) to (6), estimation using the within estimator, with cells fixed-effects where cells are either industry $\mathrm{x}$ region $\mathrm{x}$ size cells or industry $\mathrm{x}$ region cells. All regressions include a year dummy. Robust clustered standard errors at the cells level. All estimations include country and firm-level control variables. ${ }^{* * *} \mathrm{p}<0.01,{ }^{* *} \mathrm{p}<0.05,{ }^{*} \mathrm{p}<0.1$.

In our framework, there is a trade-off between solving the attrition bias and the endogeneity bias. The finer the level of analysis (firm or industry-region-size cells), the smaller is likely to be the endogeneity bias. However, the larger may be the selection issue. Indeed, despite the fact that the data is re-aggregated on cells, a large number of cells are only available for one period of time and do not provide information when 
using the within estimator with cells fixed-effects. On the other hand, the larger is the size of the cells, the larger is likely to be the endogeneity bias. But then the attrition bias is likely to be smaller since the panel is relatively more balanced.

In Columns (5) and (6) of Table 8 we therefore use cells aggregated at the industry-region level, for which the attrition bias is likely to be smaller than in Columns (3) and (4). Overall, the results are very similar to the benchmark estimations, and confirm the positive impact of aid on firms growth.

\subsection{Magnitude of the effect}

Table 2 and Table 4 suggest that a one percentage point increase in aid would increase growth by 1.50-1.77 percentage point. While the magnitude of the effect seems large compared to what is usually found in the literature, it needs to be related to the level of average growth in our sample. A firm with an average annual growth rate of 7.71 (mean value of our sample, see Table 1), would see its growth rate increase by around $20-23 \%$ if aid was increased by one percentage point.

Table 9 compares the percentage increase in growth that would stem from a one percentage point increase in aid using different regressions as benchmarks. Using firm-level estimations, we report the coefficients obtained from the OLS and fixed-effects estimations using net disbursements (Table 2) and gross disbursements (Table 4). To compare this effect to what is usually found in the literature, we use Clemens et al. (2011) who reproduce Burnside and Dollar (2000) and Rajan and Subramanian (2008) results using extended datasets. ${ }^{11}$ They find that overall a one percentage point increase in aid would increase the income growth rate by around 0.1-0.3 percentage points in the following years. ${ }^{12}$ Because these studies look at national income per capita growth rate, the average value of growth of their sample is much lower (around 1.34-1.62 annual growth rate) than the average value of firms sales growth. For example, an economy growing at $1.34 \%$ per year would see its growth rate increased by $19.8 \%$ if aid was increased by one percentage point, and assuming that a one percentage point increase in aid increases growth by 0.265 percentage point.

Table 9 suggests that (1) the OLS estimator tends to under-estimate the impact of aid, this bias being relatively larger on aggregated data than on firms data ; $(2)$ controlling for country fixed-effects (columns $(2),(4),(6)$, and (8)) leads to estimates of an impact of a one percentage point increase in aid in the range of $12 \%$ to $22 \%$ of increase in average growth. Overall, the magnitude of our results appears thus to be in line with those found in the aid growth literature.

\footnotetext{
${ }^{11}$ They also lag the aid variable.

${ }^{12}$ See footnote 27 page 609 of Clemens et al. (2011).
} 
Table 9: Magnitude of the effect and comparison with other studies.

\begin{tabular}{|c|c|c|c|c|c|c|c|c|}
\hline & \multicolumn{4}{|c|}{ Firm's sample } & \multicolumn{4}{|c|}{$\begin{array}{ll}\text { Clemens et al. (2011) } \\
\end{array}$} \\
\hline & \multicolumn{2}{|c|}{ Table 2} & \multicolumn{2}{|c|}{ Table 4} & \multicolumn{2}{|c|}{$\begin{array}{c}\text { Brunside and Dollar } \\
\text { Table } 7\end{array}$} & \multicolumn{2}{|c|}{$\begin{array}{c}\text { Rajan and Subramanian } \\
\text { Table } 9\end{array}$} \\
\hline & $\begin{array}{c}\mathrm{Col}(4) \\
\text { OLS } \\
(1) \\
\end{array}$ & $\begin{array}{c}\mathrm{Col}(5) \\
\text { WITHIN } \\
(2)\end{array}$ & $\begin{array}{c}\mathrm{Col}(4) \\
\text { OLS } \\
(3) \\
\end{array}$ & $\begin{array}{c}\operatorname{Col}(5) \\
\text { WITHIN } \\
(4)\end{array}$ & $\begin{array}{c}\mathrm{Col}(6) \\
\text { OLS } \\
(5) \\
\end{array}$ & $\begin{array}{c}\mathrm{Col}(7) \\
\mathrm{FD} \\
(6) \\
\end{array}$ & $\begin{array}{c}\mathrm{Col}(6) \\
\text { OLS } \\
(7) \\
\end{array}$ & $\begin{array}{c}\mathrm{Col}(7) \\
\mathrm{FD} \\
(8) \\
\end{array}$ \\
\hline \multicolumn{9}{|c|}{ Impact of one percentage point increase in aid: } \\
\hline In percentage point of growth & 1.346 & 1.770 & 0.943 & 1.501 & 0.117 & 0.265 & 0.070 & 0.187 \\
\hline Average growth rate & 7.71 & 7.71 & 7.71 & 7.71 & 1.34 & 1.34 & 1.62 & 1.62 \\
\hline Increase in average growth (\%) & 17.5 & 22.9 & 12.2 & 19.5 & 8.75 & 19.8 & 4.3 & 11.6 \\
\hline
\end{tabular}

The first line of Columns (5) to (8) report the estimated effect of a one percentage point increase in aid from 5.5 to 6.5 percent of GDP. Clemens et al. (2011) explain their calculation in footnote 27 page 609 of their article. The corresponding average level of growth are from Table 3 page 601 of their article.

In Columns (5) to (8) aid is lagged.

In Columns (1) and (2) net disbursements are used while in Columns (3) and (4) gross disbursements are used.

In Columns (2) and (4), WITHIN refers to the fixed-effect estimator; in Columns (6) and (8) FD refers to the estimation after first-differencing the equation.

\section{Is aid enhancing the productive capacity of firms? Indirect ev- idence of the absence of Dutch disease}

The set of previous results suggest that aid tends to enhance firms growth. The literature has highlighted some mechanisms through which aid may positively affect firms performance. Foreign aid may overall increase the productive capacity of the country, either by financing basic infrastructure or investing in human capital. However, evidence on how aid may relieve the infrastructure constraints is still scarce.

If aid were to increase the productive capacity of firms, then we should expect that it does not induce, as contrarily argued by Rajan and Subramanian (2011), a decrease in the competitiveness of firms, the so-called Dutch disease. Indeed, this is the lack of absorptive capacity of aid that is at the heart of the Dutch disease mechanism: the increase in demand provoked by aid inflows is not met by an increase in supply, hence increasing prices. If aid allows firms to increase their supply, then the pressures on prices should be lower, hence attenuating Dutch disease.

So far, our results contradict those of Rajan and Subramanian (2008) who find that aid has no impact on aggregate growth. Rajan and Subramanian (2011) explain the absence of aid impact on growth by the fact that aid induces Dutch disease, i.e. a loss of competitiveness of the firms that are most likely to export. 
The evidence they provide on the Dutch disease effect of aid is indirect. Building on the approach adopted by Rajan and Zingales (1998), they look at the effect of aid on industry growth rate for those industries that are more prone to export.

In what follows, we explore the Dutch disease effect of aid, or, more specifically the absence of Dutch disease. We interpret this absence of Dutch disease effect of aid as an indirect evidence that aid contributes to the adjustment of the supply side to the increase in demand, notably by increasing the productive capacity of the firms.

We follow Rajan and Subramanian (2011) and explore whether aid has a distinct impact on exporting firms. We therefore interact aid with a measure of 'exportability' of the firms. Like them we construct various measures of 'exportability', the most direct being a dummy for whether the firm exports its production, or part of it - EXPORTS ${ }_{i, k, j, t}$. This measure is complemented with an indicator of $\operatorname{EXPORTABILITY}_{i, k, j, t}$, which is equal to one if the firm exports more than country average. ${ }^{13}$

The results are presented in Table 10. Columns (1) and (2) highlight that foreign aid has a positive impact on firms growth independently of their proneness to export, measured either by $\operatorname{EXPORTS}_{i, k, j, t}$ (Column (1)) or EXPORTABILITY ${ }_{i, k, j, t}$ (Column (2)). This implies that the impact of aid is not different for those firms that export, indirectly suggesting the absence of Dutch disease mechanism. In Columns (3) and (4) of Table 10, we exclude from the sample the firms of the service sectors, since they are less likely to have an outward-orientation than the firms of the manufacturing sector. The results are overall consistent with the results on the full sample.

Overall, the results of the four first Columns of Table 10 provide indirect evidence for the absence of Dutch disease i.e. absence of a negative impact of aid on the outward-looking enterprises. One reason for the discrepancy between our results and those of Rajan and Subramanian (2011) may be that they aggregate their data at the industry level, while we work at the firm level. Moreover, the samples of countries are very different, which may also induce large differences in the results.

\footnotetext{
${ }^{13}$ We tested the robustness of the results to alternative definitions of 'exportability', using EXPORTABILITY $2_{i, k, j, t}(\mathrm{a}$ dummy variable which is equal to one if the firm exports more than the median of its industry in its country) and EXPORTABILITY $3_{i, k, j, t}$ (a dummy variable which is equal to one if the firm exports more than the median of all firms of the sample). Both indicators of 'exportability' lead to similar results as those presented in Table 10.
} 
Table 10: Absence of Dutch disease and firms productive capacity, indirect evidence.

\begin{tabular}{|c|c|c|c|c|c|c|c|c|}
\hline \multirow{2}{*}{$\begin{array}{l}\text { Dependent variable: } \\
\text { Sales growth }\end{array}$} & \multicolumn{2}{|c|}{ Full sample } & \multicolumn{2}{|c|}{ Without services } & \multicolumn{4}{|c|}{ "Depending on capacity } \\
\hline & $(1)$ & $(2)$ & $(3)$ & $(4)$ & $\begin{aligned} & \text { Full } \\
= & 100 \% \\
& (5)\end{aligned}$ & $\begin{array}{c}\text { No Full } \\
<100 \% \\
(6)\end{array}$ & $\begin{array}{c}\text { Full } \\
>90 \% \\
(7)\end{array}$ & $\begin{array}{c}\text { No Full } \\
<90 \% \\
(8)\end{array}$ \\
\hline $\mathrm{ODA}_{j, t}$ (gross) & $\begin{array}{c}1.501^{* *} \\
(0.563)\end{array}$ & $\begin{array}{c}1.453^{* *} \\
(0.560)\end{array}$ & $\begin{array}{l}1.824^{* *} \\
(0.709)\end{array}$ & $\begin{array}{l}1.783^{* *} \\
(0.710)\end{array}$ & $\begin{array}{c}-6.293^{* * *} \\
(2.071)\end{array}$ & $\begin{array}{l}3.669 * * \\
(1.631)\end{array}$ & $\begin{array}{c}2.564 \\
(2.178)\end{array}$ & $\begin{array}{l}4.190^{* *} \\
(1.693)\end{array}$ \\
\hline $\operatorname{ODA}_{j, t} \mathrm{xEXPORTS}_{i, k, j, t}$ & $\begin{array}{c}-0.00199 \\
(0.119)\end{array}$ & & $\begin{array}{r}0.00647 \\
(0.106)\end{array}$ & & & & & \\
\hline $\operatorname{EXPORTS}_{i, k, j, t}$ & $\begin{array}{c}5.376^{* * *} \\
(1.471)\end{array}$ & & $\begin{array}{c}4.727^{* * * *} \\
(1.560)\end{array}$ & & & & & \\
\hline ODA $_{j, t} \mathrm{xEXPORTABILITY}_{i, k, j, t}$ & & $\begin{array}{c}0.185 \\
(0.164)\end{array}$ & & $\begin{array}{c}0.124 \\
(0.155)\end{array}$ & & & & \\
\hline EXPORTABILITY $_{i, k, j, t}$ & & $\begin{array}{l}4.622^{*} \\
(2.299)\end{array}$ & & $\begin{array}{l}5.355^{*} \\
(2.811)\end{array}$ & & & & \\
\hline Observations & 9,970 & 9,970 & 7,450 & 7,450 & 890 & 6,161 & 1,779 & $\overline{5,272}$ \\
\hline R-squared & 0.247 & 0.247 & 0.256 & 0.257 & 0.778 & 0.236 & 0.432 & 0.241 \\
\hline Number of firms & 5,640 & 5,640 & 4,152 & 4,152 & 818 & 3,855 & 1,509 & 3,529 \\
\hline Number of countries & 29 & 29 & 29 & 29 & 25 & 26 & 25 & 26 \\
\hline Firms FE & yes & yes & yes & yes & yes & yes & yes & yes \\
\hline Industry x Year dummies & yes & yes & yes & yes & yes & yes & yes & yes \\
\hline
\end{tabular}

Columns (1) to (8) are estimated using the within estimator, with firms fixed-effects, industry $\mathrm{x}$ year dummies and clustered standard errors at the country level. ${ }^{* * *} \mathrm{p}<0.01,{ }^{* *} \mathrm{p}<0.05,{ }^{*} \mathrm{p}<0.1$.

The absence of evidence on a Dutch disease effect of aid suggests that the supply-side has managed to adjust to the increase in demand induced by aid inflows. This may notably be the case if aid contributes to increasing the productive capacity of the firms. As underlined by Guillaumont and Guillaumont Jeanneney (2007) the appreciation of the real exchange rate is likely to occur in the cases where the productive capacity is fully utilized. In cases where the productive capacity is under-utilized, the supply elasticity may be relatively high allowing for an adjustment of the supply-side, hence avoiding the loss of competitiveness (see Guillaumont and Guillaumont Jeanneney (2007), page 7).

The WBES provide information on the share of the productive capacity that is used by firms. The average percentage of utilization of the capacity is $70 \%$ for our sample of firms. It is $72 \%$ on average in Africa and in Latin America, and only 58\% in the two Asian countries of the sample (Pakistan and Bangladesh).

Table 10 reports the results when we distinguish the impact of aid on growth according to whether the firm's productive capacity is fully utilized or not. The impact of aid on growth is estimated on two separate 
sub-samples: (1) the sub-sample of firms which declare using $100 \%$ of their productive capacity (Full) ; (2) the sub-sample of firms which declare using less than $100 \%$ of their productive capacity (No full). Columns (5) and (6) display the results and suggest that the positive impact of aid on growth is mainly at play for firms which are under-utilizing their productive capacity. It is significantly negative when estimated on the sample of firms which declare using $100 \%$ of their capacity, consistently with the Dutch disease hypothesis. In the last two Columns of Table 10 we test the robustness of the results to changing the threshold for underutilization of capacity, in order to have more balanced sub-samples. We divide the sample using $90 \%$ of capacity utilization as the threshold. Lowering the threshold for full capacity induces a loss of significance of the coefficient of aid, which no longer has a significantly negative effect (even if under-utilization of capacity is only $10 \%$, there is prospect for supply-side adjustment). The impact of aid on firms which utilize less than $90 \%$ of their capacity (Column (6)) remains significantly positive.

\section{Does aid relax the constraints on growth?}

In the last Section of this article, we examine the mechanisms which may explain the positive impact of aid on growth and the absence of Dutch disease. One way through which aid may increase the productive capacity of the enterprises is by relaxing the infrastructure constraints that they face. We explore this mechanism and focus on two potential infrastructure constraints: access to electricity and transports. Those two constraints may be particularly acute for manufacturing firms, those whose activity is more intensive in electricity and transports.

One way to look at whether the impact of aid on growth goes through infrastructure constraints is to include them into the baseline estimations and examine whether the impact of aid is modified. If relieving the infrastructure constraint is a channel through which aid is effective then its impact should disappear, or at least diminish.

We use the following three aggregate variables for infrastructure from the World Development Indicators (2013):

- ELECTRICITY $_{j, t}$ : Electric power consumption, kwh per capita, in logarithm.

- $\mathrm{RAIL}_{j, t}$ : km of railways, in logarithm.

- $\mathrm{ROAD}_{j, t}: \mathrm{Km}$ of paved roads, in percentage of total area.

- LAGGED $\operatorname{ROAD}_{j, t-1}$ : Km of paved roads, in percentage of total area, lagged one period. 
Those infrastructure variables have a lot of missing values, implying the loss of many observations. For example, introducing $\mathrm{RAIL}_{j, t}$ into the estimation induces the loss of 10 countries and an overall loss of 3,156 observations. The same applies to all four infrastructure variables, at various degrees. Because we want to look at how the coefficient of aid evolves when the infrastructure variables are added to the baseline model, we first reproduce the baseline estimation on the restricted samples corresponding to each infrastructure variables. The results are presented in Panel A of Table 11.

Despite the change in sample, the impact of aid on firms growth remains significantly positive. Its magnitude is substantially modified by the fact that it is estimated on smaller samples - it even reaches 10,16 $\%$ in Column (2) when estimated on the (very restricted) sample of $\mathrm{RAIL}_{j, t}$.

Panel B of Table 11 presents the results when the infrastructure variables are introduced into the baseline estimations, and $\mathrm{ODA}_{j, t}$ is dropped. We find that both proxies for electricity and railways infrastructure are positive and significantly correlated with firms growth. The proxy for road infrastructure is not significant and negative. Data on roads have become poorer recently and it is therefore possible to have a better panel of countries when lagging this variable by one period. The results when LAGGED ROAD $j, t$ is substituted for $\operatorname{ROAD}_{j, t}$ are presented in Column (4) of Table 11. Of course, if we want to compare the impact of aid with and without LAGGED $\operatorname{ROAD}_{j, t}$, contemporary aid is not relevant and the right variable to use is LAGGED $\mathrm{ODA}_{j, t}$. Column (4) suggests that the density of paved road is significantly and positively correlated with firms performances in the following period. ${ }^{14}$

Finally, Panel $\mathrm{C}$ of Table 11 presents the results when $\mathrm{ODA}_{j, t}$ and the infrastructure variables are introduced simultaneously. Overall, the impact of aid remains significant, but the magnitude of the impact is reduced. In Column (1), introducing ELECTRICITY ELt $_{j}$ into the baseline estimation induces a drop in the coefficient of $\mathrm{ODA}_{j, t}$ from 2.63 to 2.42. In Column (2) the coefficient of $\mathrm{ODA}_{j, t}$ drops from 10.15 to 7.93. Finally, in Column (4), the coefficient of LAGGED ODA $j, t$ is reduced from 1.99 to 1.72. The coefficient of LAGGED ROAD $j, t$ is now only borderline significant $(\mathrm{p}$-value $=0.115)$.

\footnotetext{
${ }^{14}$ The fact that LAGGED $\operatorname{ROAD}_{j, t}$ is significant, while $\mathrm{ROAD}_{j, t}$ is not is mainly due to the change in sample. When estimated on the sample of $\operatorname{ROAD}_{j, t}$, LAGGED ROAD $j, t$ loses its significance (p-value $=0.282$ ).
} 
Table 11: Infrastructure as a channel of the aid impact on firms growth using country-level variables

\begin{tabular}{|c|c|c|c|c|}
\hline $\begin{array}{l}\text { Dependent variable: Sales growth } \\
\text { INFRASTRUCTURE: }\end{array}$ & $\begin{array}{c}(1) \\
\text { ELECTRICITY }\end{array}$ & $\begin{array}{c}(2) \\
\text { RAIL }\end{array}$ & $\begin{array}{c}(3) \\
\text { ROAD } \\
\end{array}$ & $\begin{array}{c}(4) \\
\text { LAGGED ROAD }\end{array}$ \\
\hline $\begin{array}{l}\text { Panel A } \\
\text { ODA }_{j, t} \text { gross disb., } \% \text { GDP }\end{array}$ & $\begin{array}{c}2.634^{* * *} \\
(0.869)\end{array}$ & $\begin{array}{c}10.155^{* *} \\
(4.437)\end{array}$ & $\begin{array}{l}1.588^{*} \\
(0.843)\end{array}$ & $\begin{array}{c}2.215^{* * *} \\
(0.781)\end{array}$ \\
\hline Lagged ODA $_{j, t-1}$ gross disb., $\%$ GDP & & & & $\begin{array}{l}1.999^{* *} \\
(0.756)\end{array}$ \\
\hline $\begin{array}{l}\text { Panel B } \\
\text { INFRASTRUCTURE }_{j, t}\end{array}$ & $\begin{array}{l}52.053^{* *} \\
(25.143)\end{array}$ & $\begin{array}{c}171.550^{* * *} \\
(57.646)\end{array}$ & $\begin{array}{l}-1.512 \\
(2.972)\end{array}$ & $\begin{array}{l}8.543^{* *} \\
(3.828)\end{array}$ \\
\hline $\begin{array}{l}\text { Panel C } \\
\text { ODA }_{j, t} \text { gross disb., } \% \text { GDP }\end{array}$ & $\begin{array}{c}2.415^{* * *} \\
(0.796)\end{array}$ & $\begin{array}{c}7.930^{* * *} \\
(2.340)\end{array}$ & $\begin{array}{l}1.684^{*} \\
(0.900)\end{array}$ & $\begin{array}{l}1.468^{* *} \\
(0.716)\end{array}$ \\
\hline INFRASTRUCTURE $_{j, t}$ & $\begin{array}{l}47.186^{*} \\
(23.084)\end{array}$ & $\begin{array}{c}130.485^{* * *} \\
(36.027)\end{array}$ & $\begin{array}{l}-2.330 \\
(2.727)\end{array}$ & $\begin{array}{c}6.783 \\
(4.172)\end{array}$ \\
\hline LAGGED ODA $_{j, t-1}$ gross disb., $\%$ GDP & & & & $\begin{array}{l}1.719^{* *} \\
(0.720)\end{array}$ \\
\hline Observations & 9220 & 6814 & 8657 & 9529 \\
\hline Number of firms & 5212 & 4120 & 5368 & 5577 \\
\hline Number of countries & 24 & 19 & 28 & 29 \\
\hline Firms FE & yes & yes & yes & yes \\
\hline Industry x Year dummies & yes & yes & yes & yes \\
\hline Level of se clustering & country & country & country & country \\
\hline Firm-level controls & yes & yes & yes & yes \\
\hline Country-level controls & yes & yes & yes & yes \\
\hline
\end{tabular}

Columns (1) to (4) are estimated using the within estimator, with firms fixed-effects, industry $\mathrm{x}$ year dummies and clustered standard errors at the country level. INFRASTRUCTURE ${ }_{j, t}$ is either ELECTRICITY (Column (1)), RAIL (Column (2)), ROAD (Column (3)), or LAGGED ROAD (Column (4)). ${ }^{* * *} \mathrm{p}<0.01,{ }^{* *} \mathrm{p}<0.05,{ }^{*} \mathrm{p}<0.1$.

Overall, the results of Table 11 suggest that the level of development of infrastructure is spurring firms growth in developing countries. The results are also consistent with the idea that part of aid's impact on sales growth is channeled through infrastructure.

We now turn to looking more directly at the impact of aid on firms infrastructure constraints. We proceed in two steps. First, we look at how the infrastructure constraints, measured at the firm level, influence their 
growth performance and the probability that the enterprise is under-utilizing its productive capacity. Second, we look at the impact of aid on those constraints.

\subsection{Impact of infrastructure obstacles on firms growth and capacity}

The WBES provide an assessment of the obstacles faced by firms. Indeed, the respondents are asked the kind of problem they face in their activity. Some of those assessments are more objective than others. For example, whether or not the firm had to face power outages is obviously more objective than the perception by the manager of the electricity problems faced by his firm. Those perception variables are also more prone to endogeneity issues since the firms with lower performance may be likely to have a rougher assessment of the infrastructure constraints. We therefore use various measures to provide a picture as broad as possible of the different constraints weighing on firms growth. We use the following firm-level variables to proxy the infrastructure obstacles faced by firms:

- ELECTRICITY_d $\mathrm{d}_{i, k, j, t}$ : dummy variable which is equal to one if the firm considers electricity as a major or severe obstacle.

- $\mathrm{POWER}_{i, k, j, t}$ : dummy variable which is equal to one if the firm had to face power outages during the fiscal year.

- TRANSPORT_d $\mathrm{d}_{i, k, j, t}$ : dummy variable which is equal to one if the firm considers transport as a major or severe obstacle.

- TRANSPORT_m $\mathrm{m}_{i, k, j, t}$ : dummy variable which is equal to one if the firm considers transport as its main obstacle.

Despite the fact that they are all supposed to measure the infrastructure obstacles to firms activity, those four variables tend to be weakly correlated one with the others. For example, ELECTRICITY_d $\mathrm{d}_{i, k, j, t}$ and $\operatorname{POWER}_{i, k, j, t}$ have a correlation of 0.21 (p-value $\left.=0.000\right)$. The correlation is even weaker $(0.098, \mathrm{p}$-value $=$ 0.000) for TRANSPORT_ $\mathrm{d}_{i, k, j, t}$ and TRANSPORT_ $\mathrm{m}_{i, k, j, t}$. The perception variables of the infrastructure obstacles are those which are the most correlated: ELECTRICITY_d $\mathrm{d}_{i, k, j, t}$ and TRANSPORT_d ${ }_{i, k, j, t}$ have a correlation of 0.26 (p-value $=0.000)$.

Panel A of Table 12 presents the effect of each of the constraints, introduced sequentially, on both sales growth and capacity under-utilization. When looking at the impact of the firm-level infrastructure obstacles on growth and under-capacity we exclude aid from the regressions. Indeed, infrastructure obstacles and aid 
are correlated which blurs the results when looking at the impact of any of these variables on growth. ${ }^{15}$ In columns (1) to (4), where the outcome is sales growth, we can see that not all the variables capturing the constraints at the firm-level have a significant effect on growth. However, both electricity and transport infrastructure seem to matter for firms growth. Electricity problems, captured by $\operatorname{POWER}_{i, k, j, t}$, significantly decrease the growth rate. Transport obstacles, as measured by TRANSPORT_ $\mathrm{m}_{i, k, j, t}$, also significantly decrease the growth rate of firms.

Not all the firms have answered to the questions on the obstacles to their activity. Depending on the variable used to capture the constraints, we therefore loose some observations. To check whether the results are not driven by this reduction in sample, we therefore replace the missing observations by zero and create a dummy which is equal to one when the missing point was replaced. The results are displayed in Panel B of Table 12. They are not changed by this procedure, except for TRANSPORT_m $\mathrm{m}_{i, k, j, t}$ which looses significance $(\mathrm{p}$-value $=0.129)$.

In Columns (5) to (8) of Table 12, we explore the impact of the infrastructure obstacles measured at the firm-level on whether firms under-utilize their capacity. Indeed, if we assume that aid increases the productive capacity of firms by relaxing the constraints they face, then it is important to check that those constraints do indeed imply a lower productive capacity. The dependent variable in columns (5) to (8) UNDER-CAPACITY_d $\mathrm{d}_{i, k, j, t}$ - is a dummy variable which is equal to one whenever the capacity utilization is lower than $100 \%$. We therefore switch from the within estimator to the probit estimator. In the probit estimations, along the firm-level and country-level control variables ${ }^{16}$, we also control for country dummies, industries x year dummies, and cluster the standard errors at the firm-level. Panel A of Table 12 suggests that, again both electricity (captured by POWER $_{i, k, j, t}$ ) and transport (captured by TRANSPORT_d $\mathrm{d}_{i, k, j, t}$ ) obstacles increase the probability that the firm will be under-utilizing its productive capacity. The results are confirmed in Panel B, when the missing observations are replaced by zero, suggesting that they are not driven by the reduction in sample due to missing observations for obstacles.

\footnotetext{
${ }^{15}$ The correlation of gross disbursements with $\mathrm{POWER}_{i, k, j, t}$ is $0.194^{* * *}$. It is $0.074^{* * *}$ with ELECTRICITY_d ${ }_{i, k, j, t}, 0.059^{* * *}$ with TRANSPORT_m $\mathrm{m}_{i, k, j, t}$ and $0.019^{* * *}$ with TRANSPORT_d $\mathrm{d}_{i, k, j, t}$.

${ }^{16}$ The control variables introduced in the probit estimations are the same as those introduced in the OLS estimations of Table 2.
} 
Table 12: Impact of infrastructure constraints on firms growth and capacity

\begin{tabular}{|c|c|c|c|c|c|c|c|c|}
\hline \multirow[t]{2}{*}{ Dependent variable: } & \multicolumn{4}{|c|}{ GROWTH (fixed-effect estimations) } & \multicolumn{4}{|c|}{ UNDER-CAPACITY (probit estimations) } \\
\hline & $(1)$ & $(2)$ & $(3)$ & $(4)$ & $(5)$ & $(6)$ & $(7)$ & $(8)$ \\
\hline Panel A & & & & & & & & \\
\hline $\operatorname{POWER}_{i, k, j, t}$ & $\begin{array}{c}-2.311^{* *} \\
(1.041)\end{array}$ & & & & $\begin{array}{l}0.095^{* *} \\
(0.046)\end{array}$ & & & \\
\hline ELECTRICITY_d ${ }_{i, k, j, t}$ & & $\begin{array}{c}0.219 \\
(1.028)\end{array}$ & & & & $\begin{array}{c}0.037 \\
(0.044)\end{array}$ & & \\
\hline TRANSPORT_m ${ }_{i, k, j, t}$ & & & $\begin{array}{c}-11.785^{*} \\
(5.796)\end{array}$ & & & & $\begin{array}{l}-0.191 \\
(0.170)\end{array}$ & \\
\hline TRANSPORT_d $\mathrm{d}_{i, k, j, t}$ & & & & $\begin{array}{c}1.585 \\
(1.016)\end{array}$ & & & & $\begin{array}{l}0.077^{*} \\
(0.043)\end{array}$ \\
\hline Observations & 9630 & 9940 & 8151 & 9876 & 6828 & 7034 & 5296 & 7017 \\
\hline Number of firms & 5617 & 5632 & 5497 & 5623 & 4040 & 4051 & 3896 & 4050 \\
\hline Number of countries & 29 & 29 & 29 & 29 & 26 & 26 & 26 & 26 \\
\hline Panel B & & & & & & & & \\
\hline $\operatorname{POWER}_{i, k, j, t}$ & $\begin{array}{c}-2.293^{* *} \\
(1.032)\end{array}$ & & & & $\begin{array}{c}0.079^{*} \\
(0.044)\end{array}$ & & & \\
\hline 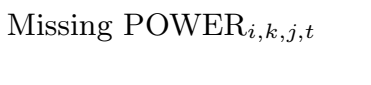 & $\begin{array}{c}3.465 \\
(7.038)\end{array}$ & & & & $\begin{array}{c}-0.313^{* *} \\
(0.132)\end{array}$ & & & \\
\hline ELECTRICITY_d ${ }_{i, k, j, t}$ & & $\begin{array}{c}0.166 \\
(1.035)\end{array}$ & & & & $\begin{array}{l}-0.006 \\
(0.043)\end{array}$ & & \\
\hline Missing ELEC_d $\mathrm{d}_{i, k, j, t}$ & & $\begin{array}{c}7.188 \\
(7.763)\end{array}$ & & & & $\begin{array}{l}-0.386 \\
(0.344)\end{array}$ & & \\
\hline TRANSPORT_m ${ }_{i, k, j, t}$ & & & $\begin{array}{c}-8.960 \\
(5.732) p=0.13\end{array}$ & & & & $\begin{array}{l}-0.182 \\
(0.166)\end{array}$ & \\
\hline Missing TRANS_m $\mathrm{m}_{i, k, j, t}$ & & & $\begin{array}{c}17.063^{* *} \\
(7.779)\end{array}$ & & & & $\begin{array}{c}0.233^{* * *} \\
(0.086)\end{array}$ & \\
\hline TRANSPORT_d $\mathrm{d}_{i, k, j, t}$ & & & & $\begin{array}{c}1.362 \\
(1.027)\end{array}$ & & & & $\begin{array}{c}0.110^{* * *} \\
(0.042)\end{array}$ \\
\hline Missing TRANS_d $\mathrm{d}_{i, k, j, t}$ & & & & $\begin{array}{l}-17.063 \\
(11.972)\end{array}$ & & & & $\begin{array}{c}0.151 \\
(0.278)\end{array}$ \\
\hline Observations & 9970 & 9970 & 9970 & 9970 & 7051 & 7051 & 7051 & 7051 \\
\hline Number of firms & 5640 & 5640 & 5640 & 5640 & 4054 & 4054 & 4054 & 4054 \\
\hline Number of countries & 29 & 29 & 29 & 29 & 26 & 26 & 26 & 26 \\
\hline Firms FE & yes & yes & yes & yes & no & no & no & no \\
\hline Country dummies & no & no & no & no & yes & yes & yes & yes \\
\hline Industry $\mathrm{x}$ Year dummies & yes & yes & yes & yes & yes & yes & yes & yes \\
\hline Clustering of st. errors & country & country & country & country & firm & firm & firm & firm \\
\hline Firm-level controls & yes & yes & yes & yes & yes & yes & yes & yes \\
\hline Country-level controls & yes & yes & yes & yes & yes & yes & yes & yes \\
\hline
\end{tabular}

Columns (1) to (4) are estimated using the within estimator, with firms fixed-effects, industry x year dummies and clustered standard errors at the country level. Columns (5) to (8) are estimated using the probit estimator, with country and industry $\mathrm{x}$ year dummies and clustered at the firm level. ${ }^{* * *} \mathrm{p}<0.01,{ }^{* *} \mathrm{p}<0.05,{ }^{*} \mathrm{p}<0.1$. 


\subsection{Impact of aid on firms' infrastructure constraints}

We now examine the impact of aid on the various infrastructure constraints measured at the firm-level. In Table 13 the dependent variables are now alternatively POWER P $_{i, k, j, t}$, ELECTRICITY_d $_{i, k, j, t}$, TRANSPORT_m ${ }_{i, k, j, t}$ and TRANSPORT_d $\mathrm{d}_{i, k, j, t}$. We use the probit estimator, controlling for firm-level and country-level characteristics, with country dummies and industry x year dummies (the standard errors are clustered at the firm-level). Panel A of Table 13 explores the impact of aggregate gross aid disbursements on those infrastructure obstacles. In Panel B to Panel D, we then turn to more disaggregated measures of aid. We use sector-level flows of gross disbursements of aid provided by the OECD-CRS.

Total sector allocable gross disbursements are disaggregated into the following broad sectors: social, economic, production and multi-sector. The so-called economic aid is further disaggregated into transport and storage, communication, energy, banking and aid to business. Given the infrastructure obstacles examined, we will focus our analysis on aid provided to the energy sector - ENERGY $_{j, t}$ - and transport and storage sector. Aid to transport and storage is further disaggregated into aid that was geolocalized on the territory of the countries (at the region level) - TRANSPORT GEOLOC. ${ }_{j, t, r}$ - and aid which we were not able to geolocalize - TRANSPORT NOT GEOLOC. ${ }_{j, t}$. To geolocalize the transport and storage aid projects we used the information contained in the description of the projects provided by the OECD-CRS. Those descriptions sometimes include information on the city or region targeted. ${ }^{17}$ For roads linking two cities in two different regions, the project was associated to the most landlocked region. Since the WBES provide information on the region where the firms are located within the country, we were then able to merge the geo-localized aid projects with the firms (at the region level). On average, we managed to geo-localize $10.6 \%$ of the 2434 transport and storage aid projects. It was easier for some countries than others, as described in Table 16 in Appendix 3. In some countries, we were not able to geo-localize any project. This is the case in Cameroon, Venezuela and Uruguay. In other countries we managed to geo-localize more than $15 \%$ of the projects: this is the case in Cap Verde, Malawi, Zambia, Chile, Columbia, Honduras, Panama.

As indicated in Table 1, ENERGY ${ }_{j, t}$ accounts on average for only $0.05 \%$ of the GDP of receiving countries. Despite the small volume of aid represented by ENERGY ${ }_{j, t}$, the number of projects in this sector is very large: 2,333. Aid to transport and storage has a higher volume (on average $0.3 \%$ of GDP) and include 2,434 projects, among which 257 project where geo-localized. ${ }^{18}$

Because the share of ENERGY Ent $_{j, t}$ in total aid is small, we also explore the impact of aid to the production

\footnotetext{
${ }^{17}$ For example, "Rehabilitation of the Faidherbe bridge in Saint-Louis in Sénégal", "Road Kati-Kita II in Mali".

${ }^{18}$ Those 257 projects account for $8.9 \%$ of the volume of aid to transport and storage.
} 
sector - PRODUCTION ${ }_{j, t}$ - on electricity constraints. The main difference between economic and production aid projects is that economic aid is not devoted to a specific industry or economic activity. Its aim is more the development of broad infrastructure. Production aid is sector and activity specific, but it may still impact the electricity constraints met by firms since its objective is to help the enterprises to increase their capacity. Some projects sometimes include providing generators or connecting to the electrical grids, for example. PRODUCTION ${ }_{j, t}$ represents, on average, $0.45 \%$ of the GDP of receiving countries, and includes 8,411 projects.

Table 13 below presents the results of the effect of both aggregate aid disbursements (Panel A) and sector aid (Panels B, C and D) on both electricity and transport problems. When sector aid is included, we also control for other aid, which is constructed as total gross disbursements minus aid targeted to the specific sector. The probit estimations for ELECTRICITY_d $\mathrm{d}_{i, k, j, t}$ seems to give the best results. The regression

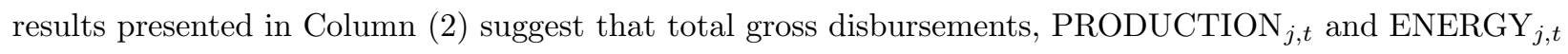
all tend to reduce the perception by firms that electricity is a major or severe obstacle to their activity. Only PRODUCTION $_{j, t}$ seems to influence the more objective measure of firms electricity obstacles, POWER $i, k, j, t$.

We next turn to the impact of gross disbursements, and sector aid on transport obstacles. Contrary to their impact on electricity obstacles, total gross disbursements do not influence the level of transport obstacles. In the Panel D, we include TRANSPORT GEOLOC. ${ }_{j, r}, t$, non geo-localized aid to transport (TRANSPORT NOT GEOLOC. ${ }_{j, t}$ ), and other gross disbursements. We find that when aid projects to transport are located in the same region as the firm' region, then it is significantly and negatively correlated with the perception of transport as being a severe obstacle to the firm activity. This result appears for both variables measuring transport problems in columns (3) and (4). 


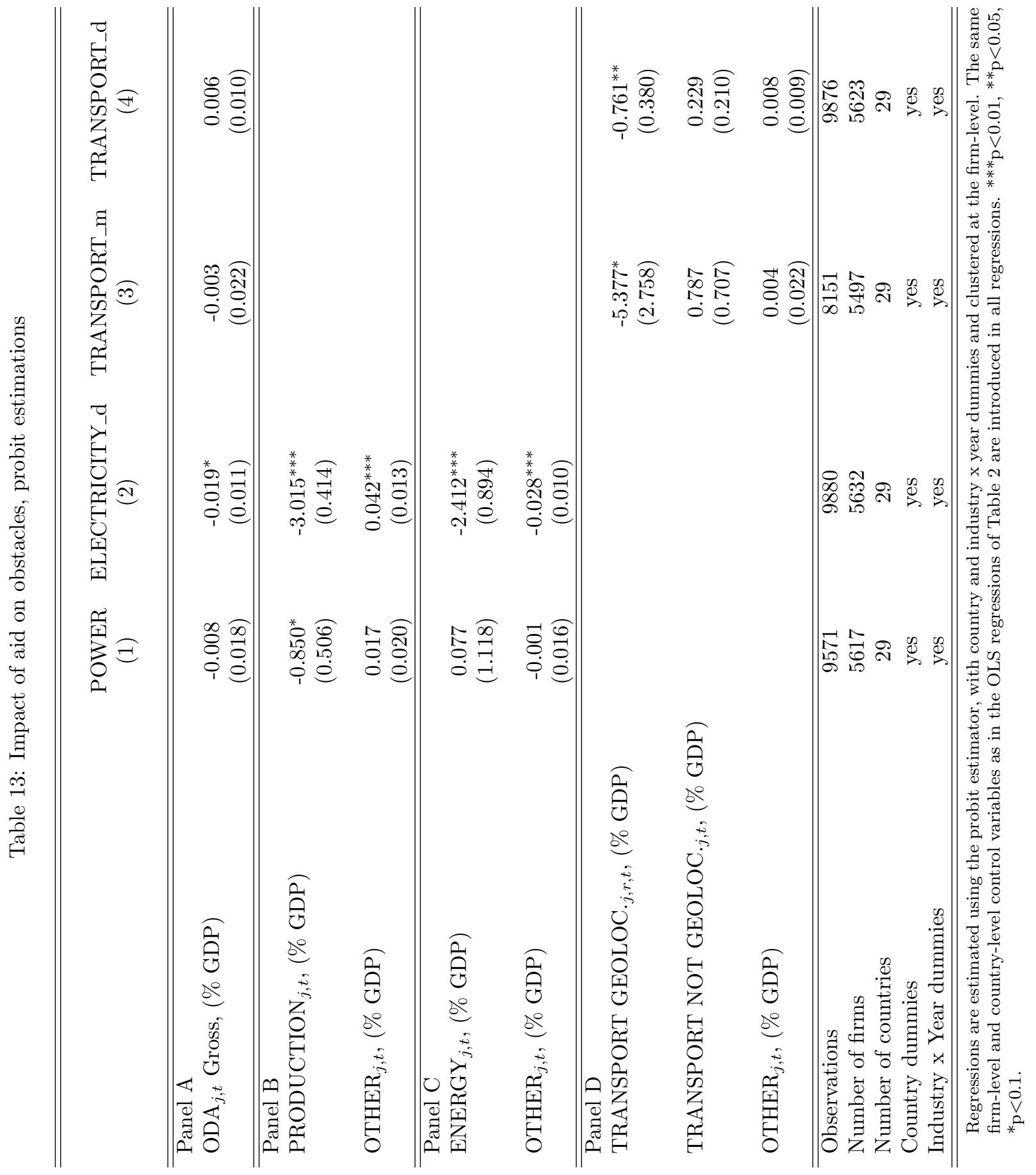




\section{Conclusion}

This paper explores the impact of foreign aid on firms growth for a panel of 5,640 firms in 29 developing countries. Using the World Bank Enterprise Surveys data and controlling for firms fixed-effects, we find a positive impact of foreign aid on sales growth. This result is robust to various checks, notably to using the two-stage least squares estimator and to dropping one country at the time.

Consistently with the positive impact of aid on firms' growth, we find no evidence of a Dutch disease effect of aid. More specifically, firms that do not fully utilize their productive capacity are positively affected by aid, while firms that fully utilize their capacity are negatively affected by aid disbursements. This result suggests that aid contributes to the supply-side adjustment to the increase in demand it provokes.

We then explore one specific channel through which aid may increase sales growth and the productive capacity of firms: the infrastructure channel. We identify the main infrastructure constraints weighting on firms growth and examine whether foreign aid contributes to relaxing those constraints. We provide evidence that electricity and transport obstacles are perceived as important constraints which tend to both decrease the growth rates of firms and limit their capacity utilization. We then show that total aid tends to decrease the electricity obstacle, as well as aid to the production and energy sectors. Our analysis does not provide any evidence of an impact of total aid on transport obstacles. However, once transport aid projects are partially geo-localized on the countries' territories, we find that they tend to decrease the transport obstacles of firms located in the targeted regions.

This article overall underlines that exploiting intra-country variation in the outcome on which aid effectiveness is assessed has many advantages. First, from a methodological point of view, this approach largely attenuates the endogeneity issues which have so far led to huge skepticism regarding the conclusions of the empirical analyses at the aggregate level. Second, this approach opens the way to a finer analysis of aid effectiveness. As is shown in this article, aid effectiveness may depend on the characteristics of firms, and notably whether they are outward-looking and fully utilizing their productive capacity. It may also depend on whether the regions are, or are not, targeted by specific sector aid. 


\section{References}

Angeles, L. and Neanidis, K. C. (2009), "Aid effectiveness: the role of the local elite", Journal of Development Economics, vol. $90 \mathrm{n}^{\circ}$ 1: pp. 120-134.

Arndt, C., Jones, S. and TARP, F. (2010), “Aid, growth, and development: have we come full circle?", Journal of Globalization and Development, vol. $1 \mathrm{n}^{\circ}$ 2: pp. 1-29.

Bas, M. and Berthou, A. (2012), "The Decision to Import Capital Goods in India: Firms' Financial Factors Matter", The World Bank Economic Review, vol. 26 n 3: pp. 486-513.

Beck, T., Demirguc-Kunt, A. and Maksimovic, V. (2005), "Financial and Legal Constraints to Growth: Does Firm Size Matter?", Journal of Finance, vol. 60 no 1: pp. 137-177.

Berman, N. and Héricourt, J. (2010), "Financial factors and the margins of trade: Evidence from cross-country firm-level data", Journal of Development Economics, vol. 93: pp. 206-217.

BJøRnskov, C. (2010), "Do elites benefit from democracy and foreign aid in developing countries?", Journal of Development Economics, vol. $92 \mathrm{n}^{\mathrm{o}} 2$ : pp. 115-124.

Burnside, C. and Dollar, D. (2000), "Aid, policies, and growth”, American economic review, vol. 37 n 6 : pp. 847-868.

Calderon, C. and Serven, L. (2008), "Infrastructure and economic development in Sub-Saharan Africa", Policy Research Working Paper Series 4712, The World Bank.

Chauvet, L. and Jacolin, L. (2014), The impact of financial inclusion on firms exports in developing countries, mimeo.

Chauvet, L. and Mesplé-Somps, S. (2007), "Impact des financements internationaux sur les inégalités des pays en développement", Revue Economique, vol. 58 n 3: pp. 735-744.

Chauvet, L., Gubert, F. and Mesplé-Somps, S. (2013), “Aid, Remittances, Medical Brain Drain and Child Mortality: Evidence Using Inter and Intra-Country Data", The Journal of Development Studies, vol. $49 \mathrm{n}^{\mathrm{o}}$ 6: pp. 801-818.

Chong, A. and Gradstein, M. (2009), "Volatility and firm growth", Journal of Economic Growth, vol. 14 n ${ }^{\circ}$ 1: pp. 1-25. 
Clemens, M. A., Radelet, S., Bhavnani, R. R. and Bazzi, S. (2011), "Counting Chickens when they Hatch: Timing and the Effects of Aid on Growth", The Economic Journal, vol. $122 \mathrm{n}^{\circ}$ 561: pp. 590-617.

Collier, P. and Dehn, J. (2001), “Aid, shocks, and growth”, Policy Research Working Paper Series 2688, The World Bank.

Collier, P. and Hoeffler, A. (2004), "Aid, policy and growth in post-conflict societies", European

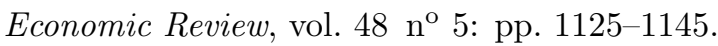

Dalgaard, C.-J., Hansen, H. and Tarp, F. (2004), "On the empirics of foreign aid and growth", The Economic Journal, vol. 114 n $^{\circ}$ 496: pp. F191-F216.

DatTA, S. (2012), "The impact of improved highways on Indian firms", Journal of Development Economics, vol. $99 \mathrm{n}^{\circ}$ 1: pp. $46-57$.

Dollar, D., Hallward-Driemeier, M. and Mengistae, T. (2005), "Investment Climate and Firm Performance in Developing Economies", Economic Development and Cultural Change, vol. $54 \mathrm{n}^{\circ}$ 1: pp. $1-31$.

Dreher, A., Nunnenkamp, P. and Thiele, R. (2008), "Does aid for education educate children? Evidence from panel data", The World Bank Economic Review, vol. 22 n 2: pp. 291-314.

Ebeke, C. and Drabo, A. (2011), "Remittances, public health spending and foreign aid in the access to health care services in developing countries", Etudes et Documents du CERDI.

Eifert, B., Gelb, A. and Ramachandran, V. (2008), "The Cost of Doing Business in Africa: Evidence from Enterprise Survey Data", World Development, vol. 36 nº 9: pp. 1531-1546.

Fisman, R. and Svensson, J. (2007), "Are corruption and taxation really harmful to growth? Firm level evidence", Journal of Development Economics, vol. 83 n 1: pp. 63-75.

Guillaumont, P. and Chauvet, L. (2001), "Aid and performance: a reassessment", Journal of Development Studies, vol. $37 \mathrm{n}^{\circ}$ 6: pp. 66-92.

Guillaumont, P. and Guillaumont Jeanneney, S. (2007), Big push versus absorptive capacity: how to reconcile the two approaches, 2007/05, WIDER Discussion Papers, World Institute for Development Economics (UNU-WIDER). 
Hansen, H. and Tarp, F. (2000), "Aid effectiveness disputed", Foreign Aid and Development: Lessons Learnt and Directions for the Future, pp. 103-128.

HAnsen, H. and TARP, F. (2001), "Aid and growth regressions", Journal of Development Economics, vol. 64 $\mathrm{n}^{\mathrm{O}} 2$ : pp. $547-570$.

Harrison, A. E., Lin, J. Y. and Xu, L. C. (2013), "Explaining Africa's (Dis)advantage", Technical report 18683, National Bureau of Economic Research.

Kaufmann, D., Kraay, A. and Mastruzzi, M. (2011), "The worldwide governance indicators: methodology and analytical issues", Hague Journal on the Rule of Law, vol. 3 n 2: pp. 220-246.

Limao, N. and Venables, A. J. (2001), "Infrastructure, Geographical Disadvantage, Transport Costs, and Trade", The World Bank Economic Review, vol. 15 n 3: pp. 451-479.

Michaelowa, K. and Weber, A. (2006), "Aid effectiveness in the education sector: A Dynamic panel analysis", Frontiers of Economics and Globalization, vol. 1: pp. 357-385.

Mitra, A., Varoudakis, A. and Veganzones-Varoudakis, M.-A. (2002), "Productivity and technical efficiency in Indian States' manufacturing: the role of infrastructure", Economic Development and Cultural Change, vol. 50: pp. 395-426.

Rajan, R. G. and Subramanian, A. (2008), "Aid and growth: What does the cross-country evidence really show?", The Review of economics and Statistics, vol. $90 \mathrm{n}^{\circ}$ 4: pp. 643-665.

Rajan, R. G. and Subramanian, A. (2011), "Aid, Dutch disease, and manufacturing growth", Journal of Development Economics, vol. $94 \mathrm{n}^{\mathrm{o}}$ 1: pp. 106-118.

Rajan, R. G. and Zingales, L. (1998), "Financial Dependence and Growth", American Economic Review, pp. 559-586.

Roodman, D. (2007), "The anarchy of numbers: aid, development, and cross-country empirics", The World Bank Economic Review, vol. $21 \mathrm{n}^{\circ}$ 2: pp. 255-277.

RuD, J. P. (2012), "Electricity provision and industrial development: Evidence from India", Journal of Development Economics, vol. 97 n 2 : pp. 352-367.

Straub, S. (2008), "Infrastructure and growth in developing countries : recent advances and research challenges", Policy Research Working Paper Series 4460, The World Bank. 
TAvares, J. (2003), "Does foreign aid corrupt?", Economics Letters, vol. 79 n 1: pp. 99-106. 
Table 14: Appendix 1. List of countries, years of surveys, and number of observations.

\begin{tabular}{|c|c|c|c|c|c|c|c|c|}
\hline \multicolumn{3}{|c|}{ Latin America } & \multicolumn{3}{|c|}{ Africa } & \multicolumn{3}{|c|}{ Asia } \\
\hline Country & Survey & $\mathrm{N}$ & Country & Survey & $\mathrm{N}$ & Country & Survey & $\mathrm{N}$ \\
\hline Argentina & $(2006,2010)$ & 842 & Burkina Faso & $(2006,2009)$ & 159 & Bangladesh & $(2007,2011)$ & 444 \\
\hline Bolivia & $(2006,2010)$ & 218 & Botswana & $(2006,2010)$ & 207 & Pakistan & $(2002,2007)$ & 744 \\
\hline Brazil & $(2003,2009)$ & 828 & Cameroon & $(2006,2009)$ & 142 & & & \\
\hline Chile & $(2006,2010)$ & 732 & Cape Verde & $(2006,2009)$ & 103 & & & \\
\hline Colombia & $(2006,2010)$ & 539 & Mali & $(2007,2010)$ & 258 & & & \\
\hline Ecuador & $(2006,2010)$ & 280 & Malawi & $(2005,2009)$ & 134 & & & \\
\hline El Salvador & $(2006,2010)$ & 178 & Morocco & $(2004,2007)$ & 528 & & & \\
\hline Guatemala & $(2006,2010)$ & 221 & Niger & $(2005,2009)$ & 96 & & & \\
\hline Honduras & $(2003,2006)$ & 404 & Senegal & $(2003,2007)$ & 127 & & & \\
\hline Mexico & $(2006,2010)$ & 362 & South Africa & $(2003,2007)$ & 339 & & & \\
\hline Nicaragua & $(2003,2006)$ & 455 & Zambia & $(2002,2007)$ & 120 & & & \\
\hline Panama & $(2006,2010)$ & 143 & & & & & & \\
\hline Peru & $(2006,2010)$ & 557 & & & & & & \\
\hline Paraguay & $(2006,2010)$ & 216 & & & & & & \\
\hline Uruguay & $(2006,2010)$ & 414 & & & & & & \\
\hline Venezuela & $(2006,2010)$ & 180 & & & & & & \\
\hline Total & $6,569\left(66^{\circ}\right.$ & & & $2,213(22)$ & & & $1,188(129$ & \\
\hline
\end{tabular}


Table 15: Appendix 2. Stability of the results when each country is omitted.

\begin{tabular}{lclcl}
\hline \hline & \multicolumn{2}{c}{$(1)$} & \multicolumn{2}{c}{$(2)$} \\
& \multicolumn{2}{c}{ Net Disbursments } & \multicolumn{2}{c}{ Gross Disbursments } \\
& \multicolumn{2}{c}{ FE } & \multicolumn{2}{c}{ FE } \\
\hline \hline Full sample & $1.770^{* *}$ & $(0.641)$ & $1.501^{* *}$ & $(0.555)$ \\
Observations & 9970 & & 9970 & \\
\hline \hline ARG & $1.836^{* *}$ & $(0.731)$ & $1.620^{* * *}$ & $(0.526)$ \\
Observations & 9128 & & 9128 & \\
\hline \hline CHL & $1.945^{* *}$ & $(0.833)$ & $1.913^{* * *}$ & $(0.566)$ \\
Observations & 9238 & & 9238 & \\
\hline \hline COL & $1.564^{* *}$ & $(0.672)$ & $1.494^{* * *}$ & $(0.532)$ \\
Observations & 9431 & & 9431 & \\
\hline \hline BOL & $2.476^{* * *}$ & $(0.853)$ & $1.689^{* *}$ & $(0.663)$ \\
Observations & 9752 & & 9752 & \\
\hline \hline ECU & $1.772^{* *}$ & $(0.721)$ & $1.475^{* *}$ & $(0.562)$ \\
Observations & 9690 & & 9690 & \\
\hline \hline GTM & $1.747^{* *}$ & $(0.686)$ & $1.529^{* *}$ & $(0.564)$ \\
Observations & 9749 & & 9749 & \\
\hline \hline HND & $1.656^{* *}$ & $(0.650)$ & $1.532^{* *}$ & $(0.570)$ \\
Observations & 9566 & & 9566 & \\
\hline \hline MEX & $1.492^{*}$ & $(0.851)$ & $1.358^{* *}$ & $(0.523)$ \\
Observations & 9608 & & 9608 & \\
\hline \hline NIC & $2.124^{* * *}$ & $(0.722)$ & $1.560^{* *}$ & $(0.592)$ \\
Observations & 9515 & & 9515 & \\
\hline \hline SLV & $1.609^{* *}$ & $(0.752)$ & $1.461^{* *}$ & $(0.555)$ \\
Observations & 9792 & & 9792 & \\
\hline \hline PAN & $1.761^{* *}$ & $(0.667)$ & $1.523^{* *}$ & $(0.558)$ \\
Observations & 9827 & & 9827 & \\
\hline \hline PER & $1.692^{* *}$ & $(0.628)$ & $1.479^{* * *}$ & $(0.533)$ \\
Observations & 9413 & & 9413 & \\
\hline \hline PRY & $1.656^{* *}$ & $(0.745)$ & $1.517^{* * *}$ & $(0.545)$ \\
Observations & 9754 & & 9754 & \\
\hline \hline ObRY & $1.565^{*}$ & $(0.786)$ & $1.459^{* *}$ & $(0.536)$ \\
Observations & 9556 & & 9556 & \\
\hline \hline ObEN & $1.674^{* *}$ & $(0.717)$ & $1.498^{* *}$ & $(0.590)$ \\
Observations & 9790 & & 9790 & \\
\hline \hline BRA & $1.782^{* *}$ & $(0.757)$ & $1.593^{* *}$ & $(0.599)$ \\
\hline & 9142 & & 9142 & \\
\hline
\end{tabular}


Table 15: Appendix 2. continued.

\begin{tabular}{|c|c|c|c|c|}
\hline \multirow{3}{*}{$\begin{array}{l}\text { Full sample } \\
\text { Observations }\end{array}$} & \multicolumn{2}{|c|}{$\begin{array}{c}\text { (1) } \\
\text { Net Disbursments } \\
\text { FE }\end{array}$} & \multicolumn{2}{|c|}{$\begin{array}{c}(2) \\
\text { Gross Disbursments } \\
\text { FE }\end{array}$} \\
\hline & $1.770^{* *}$ & $(0.641)$ & $1.501^{* *}$ & $(0.555)$ \\
\hline & 9970 & & 9970 & \\
\hline BFA & $2.024^{* * *}$ & $(0.629)$ & $1.025^{* *}$ & $(0.374)$ \\
\hline Observations & 9811 & & 9811 & \\
\hline CMR & $1.333^{*}$ & $(0.665)$ & $1.432^{* *}$ & $(0.635)$ \\
\hline Observations & 9828 & & 9828 & \\
\hline ZMB & $2.010^{* *}$ & $(0.780)$ & $1.417^{* * *}$ & $(0.509)$ \\
\hline Observations & 9850 & & 9850 & \\
\hline CPV & $1.724^{* *}$ & $(0.759)$ & $1.552^{* *}$ & $(0.602)$ \\
\hline Observations & 9867 & & 9867 & \\
\hline MLI & $1.705^{* *}$ & $(0.754)$ & $1.655^{* *}$ & $(0.598)$ \\
\hline Observations & 9712 & & 9712 & \\
\hline$\overline{\mathrm{MWI}}$ & $1.543^{*}$ & $(0.867)$ & $2.617^{* * *}$ & $(0.926)$ \\
\hline Observations & 9836 & & 9836 & \\
\hline NER & $1.548^{*}$ & $(0.879)$ & $2.478^{* *}$ & $(0.900)$ \\
\hline Observations & 9874 & & 9874 & \\
\hline MAR & $1.959^{* * *}$ & $(0.524)$ & $1.493^{* *}$ & $(0.587)$ \\
\hline Observations & 9442 & & 9442 & \\
\hline BWA & $1.661^{*}$ & $(0.916)$ & $1.502^{* *}$ & $(0.596)$ \\
\hline Observations & 9763 & & 9763 & \\
\hline$\overline{\mathrm{ZAF}}$ & $1.600^{* *}$ & $(0.674)$ & $0.964^{* *}$ & $(0.421)$ \\
\hline Observations & 9631 & & 9631 & \\
\hline SEN & $1.746^{* *}$ & $(0.768)$ & $1.651^{* * *}$ & $(0.593)$ \\
\hline Observations & 9843 & & 9843 & \\
\hline
\end{tabular}

Columns (1) and (2) are estimated using the within estimator, with firms fixed-effects, industry $\mathrm{x}$ year dummies and clustered standard errors at the country level. ${ }^{* * *} \mathrm{p}<0.01,{ }^{* *} \mathrm{p}<0.05,{ }^{*} \mathrm{p}<0.1$. 
Table 16: Appendix 3. Geo-localized projects

\begin{tabular}{|c|c|c|c|c|c|c|c|c|c|}
\hline \multirow{2}{*}{ Country } & & \multicolumn{3}{|c|}{ Transport Projects } & \multirow{2}{*}{ Country } & & \multicolumn{3}{|c|}{ Transport Projects } \\
\hline & & Not geoloc & Geoloc & Total & & & Not geoloc & Geoloc & Total \\
\hline \multirow[t]{2}{*}{ BFA } & $\mathrm{Nb}$ & 96 & 8 & 104 & ARG & $\mathrm{Nb}$ & 28 & 3 & 31 \\
\hline & $\%$ & 92.31 & 7.69 & 100.00 & & $\%$ & 90.32 & 9.68 & 100.00 \\
\hline \multirow[t]{2}{*}{ BWA } & $\mathrm{Nb}$ & 27 & 4 & 31 & BOL & $\mathrm{Nb}$ & 94 & 7 & 101 \\
\hline & $\%$ & 87.10 & 12.90 & 100.00 & & $\%$ & 93.07 & 6.93 & 100.00 \\
\hline \multirow{2}{*}{ CMR } & $\mathrm{Nb}$ & 249 & 0 & 249 & BRA & $\mathrm{Nb}$ & 65 & 11 & 76 \\
\hline & $\%$ & 100.00 & 0.00 & 100.00 & & $\%$ & 85.53 & 14.47 & 100.00 \\
\hline \multirow{2}{*}{ CPV } & $\mathrm{Nb}$ & 92 & 17 & 109 & CHL & $\mathrm{Nb}$ & 43 & 8 & 51 \\
\hline & $\%$ & 84.40 & 15.60 & 100.00 & & $\%$ & 84.31 & 15.69 & 100.00 \\
\hline \multirow[t]{2}{*}{ MAR } & $\mathrm{Nb}$ & 122 & 14 & 136 & $\mathrm{COL}$ & $\mathrm{Nb}$ & 52 & 10 & 62 \\
\hline & $\%$ & 89.71 & 10.29 & 100.00 & & $\%$ & 83.87 & 16.131 & 100.00 \\
\hline \multirow[t]{2}{*}{ MLI } & $\mathrm{Nb}$ & 109 & 18 & 127 & ECU & $\mathrm{Nb}$ & 42 & 5 & 47 \\
\hline & $\%$ & 85.83 & 14.17 & 100.00 & & $\%$ & 89.36 & 10.64 & 100.00 \\
\hline \multirow[t]{2}{*}{ MWI } & $\mathrm{Nb}$ & 76 & 29 & 105 & GTM & $\mathrm{Nb}$ & 53 & 2 & 55 \\
\hline & $\%$ & 72.38 & 27.62 & 100.00 & & $\%$ & 96.36 & 3.64 & 100.00 \\
\hline \multirow[t]{2}{*}{ NER } & $\mathrm{Nb}$ & 70 & 4 & 74 & HND & $\mathrm{Nb}$ & 71 & 16 & 87 \\
\hline & $\%$ & 94.59 & 5.41 & 100.00 & & $\%$ & 81.61 & 18.39 & 100.00 \\
\hline \multirow[t]{2}{*}{ SEN } & $\mathrm{Nb}$ & 93 & 13 & 106 & MEX & $\mathrm{Nb}$ & 75 & 11 & 86 \\
\hline & $\%$ & 87.74 & 12.26 & 100.00 & & $\%$ & 87.21 & 12.79 & 100.00 \\
\hline \multirow[t]{2}{*}{$\mathrm{ZAF}$} & $\mathrm{Nb}$ & 32 & 2 & 34 & NIC & $\mathrm{Nb}$ & 51 & 7 & 58 \\
\hline & $\%$ & 94.12 & 5.88 & 100.00 & & $\%$ & 87.93 & 12.07 & 100.00 \\
\hline \multirow[t]{2}{*}{$\mathrm{ZMB}$} & $\mathrm{Nb}$ & 106 & 23 & 129 & PAN & $\mathrm{Nb}$ & 32 & 6 & 38 \\
\hline & $\%$ & 82.17 & 17.83 & 100.00 & & $\%$ & 84.21 & 15.79 & 100.00 \\
\hline Total & $\mathrm{Nb}$ & 1,072 & 132 & 1,204 & PER & $\mathrm{Nb}$ & 84 & 6 & 90 \\
\hline \multirow[t]{3}{*}{ Africa } & $\%$ & 89.04 & 10.96 & 100.00 & & $\%$ & 93.33 & 6.67 & 100.00 \\
\hline & & & & & PRY & $\mathrm{Nb}$ & 27 & 2 & 29 \\
\hline & & & & & & $\%$ & 93.10 & 6.90 & 100.00 \\
\hline \multirow[t]{2}{*}{ BGD } & $\mathrm{Nb}$ & 224 & 19 & 243 & SLV & $\mathrm{Nb}$ & 47 & 4 & 51 \\
\hline & $\%$ & 92.18 & 7.82 & 100.00 & & $\%$ & 92.16 & 7.84 & 100.00 \\
\hline \multirow[t]{2}{*}{ PAK } & $\mathrm{Nb}$ & 91 & 8 & 99 & URY & $\mathrm{Nb}$ & 11 & 0 & 11 \\
\hline & $\%$ & 91.92 & 8.08 & 100.00 & & $\%$ & 100.00 & 0.00 & 100.00 \\
\hline Total & $\mathrm{Nb}$ & 315 & 27 & 342 & VEN & $\mathrm{Nb}$ & 15 & 0 & 15 \\
\hline \multirow[t]{3}{*}{ Asia } & $\%$ & 92.11 & 7.89 & 100.00 & & $\%$ & 100.00 & 0.00 & 100.00 \\
\hline & & & & & Total & $\mathrm{Nb}$ & 790 & 98 & 888 \\
\hline & & & & & Latin America & $\%$ & 88.96 & 11.04 & 100.00 \\
\hline
\end{tabular}

